NBER WORKING PAPER SERIES

SELF-EMPLOYMENT: MORE MAY NOT BE BETTER

David G. Blanchflower

Working Paper 10286

http://www.nber.org/papers/w10286

NATIONAL BUREAU OF ECONOMIC RESEARCH

1050 Massachusetts Avenue

Cambridge, MA 02138

February 2004

I thank Matthias Benz, Bruno Frey, Andrew Oswald and participants at a seminar at the University of Warwick for helpful comments. All errors are mine. The views expressed herein are those of the authors and not necessarily those of the National Bureau of Economic Research.

(C)2004 by David G. Blanchflower. All rights reserved. Short sections of text, not to exceed two paragraphs, may be quoted without explicit permission provided that full credit, including $@$ notice, is given to the source. 
Self-Employment: More may not be better

David G. Blanchflower

NBER Working Paper No. 10286

February 2004

JEL No. J4

\begin{abstract}
I present information on self-employment from seventy countries. Self-employment rates are generally down across the OECD. The main exceptions are the UK, and New Zealand. The probability of being self-employed across the OECD is higher for men and for older workers compared with younger workers. In Europe the probabilities are lower the more educated an individual is, while the opposite is true in the US. Some groups of immigrants have higher rates of self-employment than the indigenous population, others do not. Capital constraints appear to bind especially tightly in the US for firms owned by minorities and women: the low rates of selfemployment of blacks and Hispanics in the US appears in part to be driven by liquidity constraints. There is evidence that liquidity constraints bite in other countries including the UK, Finland, Australia, Canada and Sweden.
\end{abstract}

It does seem likely that people have an unrealistically rosy view of what it is like to be running their own business rather than staying with the comparative security of being an employee. A surprisingly high proportion of employees say they would prefer to be self-employed. Despite the fact that very high proportions of employees say they would like to set up their own business the reality is something else. The evidence presented her suggests that people may well be able to judge what is in their own best interests - that is why they remain as employees. The self-employed work under a lot of pressure, report that they find their work stressful and that they come home from work exhausted. Further, they report being constantly under strain, that they lose sleep over worry and place more weight on work than they do on leisure. However, they are especially likely to say they have control over their lives as well as being highly satisfied with their lives.

David G. Blanchflower

Department of Economics

6106 Rockefeller Hall

Dartmouth College

Hanover, NH 03755-3514

and NBER

blanchflower@dartmouth.edu 
I first started working on self-employment in 1988. I always thought it was an interesting topic, not least because Andrew Oswald and I came up with what we thought was a great title - 'What makes an entrepreneur?'. Nobody else seemed to care much about understanding the make-up of the elusive entrepreneur despite the fact that he or she is central to the core theories all economists teach. That first paper was extremely difficult to publish at a major journal: it went through numerous revisions and size changes and was rejected summarily. It was eventually published in long form in the Journal of Labor Economics in 1998. The field was thin then - the only American labor economists to my knowledge who were working in the area were George Borjas and David Evans. I recall the editor Fran Blau saying to us that it was time the paper was published as even in its working paper form it had generated a fairly substantial published literature. There was a ten year time lag from the time we first started working on it to when it was eventually published, which even for economics is unusually long. It is in the top three of my most favourite Blanchflower and Oswald papers - of which there have been at least a hundred I believe in one form or another. I am pleased to say though that 'What Makes an Entrepreneur' does seem to have been quite influential - according to the Social Science Citations Index, as of November 2003 it had been cited a creditable 70 times. The National Bureau of Economic Research has now even started an Entrepreneurship group led by Josh Lerner. The study of self-employment appears, at long last, to have come of age.

In this paper I extend work first published in Labour Economics in 2000. I will also introduce new evidence on the stresses and strains and pressures that the self-employed face, particularly when they have employees. I present macro evidence across 30 OECD countries alongside evidence from micro-surveys on seventy countries drawn from both rich and poor countries, from the developed and the developing world, on over five million individuals. ${ }^{1}$ The main comparisons I draw, however, are between the United States and European countries in general and the European Union in particular. I make use of data from the Outgoing Rotation Group files of the Current Population Survey ${ }^{2}(\mathrm{ORG})$ and the General Social Survey (GSS) for the United States along with multiple country data drawn from the World Values Survey (WVS) ${ }^{3}$, the Eurobarometer Surveys (EBS) ${ }^{4}$ and the International Social Survey Programme (ISSP). ${ }^{5}$

\footnotetext{
${ }^{1}$ The countries are Andalusia, Argentina, Armenia, Australia, Austria, Azerbaijan, Bangladesh, Basque, Belarus, Belgium, Bosnia-Herzegovina, Brazil, Bulgaria, Canada, Chile, China, Croatia, Czech Republic, Cyprus, Denmark, Dominican Republic, East Germany, Estonia, Finland, France, Galicia, Georgia, Great Britain, Greece, Hungary, Iceland, India, Ireland, Israel, Italy, Japan, Korea, Latvia, Lithuania, Luxembourg, Macedonia, Mexico, Moldova, Montenegro, Moscow, Netherlands, New Zealand, Nigeria, Northern Ireland, Norway, Peru, Philippines, Poland, Portugal, Romania, Russia, Serbia, Slovakia, Slovenia, South Africa, Spain, Sweden, Switzerland, Tambov, Turkey, Ukraine, Uruguay, USA, Valencia, Venezuela and West Germany.

2 For details of the Current Population Survey see the National Bureau of Economic Research's website http://www.nber.org/data/cps index.html

3 The World Values Survey series is designed to enable a cross-national comparison of values and norms on a wide variety of topics and to monitor changes in values and attitudes across the globe. This data collection consists of responses from World Values Survey, 1981-1983 (ICPSR \#9309) and World Values Survey, 1981-1984 and 19901993 (ICPSR \#6160), along with data gathered during 1995-1997. Over 60 surveys representing more than 50 countries participated in the 1995-1997 study. For details of the World Values Survey see codebook ICPSR\#2790 available at www.icpsr.umich.edu

${ }^{4}$ http://www.za.uni-koeln.de/data/en/eurobarometer/index.htm
} 
These latter three survey series have the advantage that they collect individual level data at different points of time across many countries using identical sample designs and questionnaires. For example, the EBS surveys collects data for the European Union in each member country at least twice a year ${ }^{6}$ while the ISSP collects data annually: the WVS has had three sweeps.

In the first section I review the literature. In section two I examine trends in self-employment by country using both aggregated and disaggregated data for many countries but with special emphasis on comparisons between the USA and Europe. I present evidence on the determinants of self-employment by country - including by time, sector, age, race, gender, immigrant status and level of education. In section three I look at the evidence first presented in Blanchflower, Oswald and Stutzer (2001) that there is a huge unfilled demand to be self-employed by those working as employees. Section four examines the reasons why that might be using data from the fifteen member countries of the EU and the United States. I replicate the well known finding that the self-employed are more satisfied with their jobs than is true of employees. This is true across most OECD countries - the main exceptions are Austria, Finland and Greece. I find that, in comparison with employees, the self-employed are also more satisfied with their pay, the type of work they do and like the fact that they have short commuting times. The paper distinguishes a number of less desirable aspects of being self-employed which do not appear to have been quantified previously. The results help to explain why so many of those express a desire to become self-employed are thwarted in that desire, not least of which is the difficulty in obtaining

5 The International Social Survey Program (ISSP) is a continuing, annual program across countries that brings together pre-existing, social science projects and coordinates research goals, thereby adding a cross- national perspective to the individual, national studies. It first started in the early 1980s when the organizations running preexisting surveys - the German ALLBUS Surveys, the US General Social Surveys, the Australian Social Survey and the British Social Attitudes Survey agreed to 1) jointly develop topical modules dealing with important areas of social science, 2) field the modules as a fifteen-minute supplement to the regular national surveys (or a special survey if necessary), 3) include an extensive common core of background variables, and 4) make the data available to the social science community as soon as possible. Since 1984, ISSP has grown to 38 nations - Australia, Austria, Brazil, Bulgaria, Canada, Chile, Cyprus, Czech Republic, Denmark, Finland, France, Germany, Great Britain, Hungary, Ireland, Israel, Italy, Japan, Latvia, Mexico, Netherlands, New Zealand, Norway, Philippines, Poland, Portugal, Russia, Slovakia, Slovenia, South Africa, Spain, South Korea, Sweden, Switzerland, Taiwan, Uruguay, USA, Venezuela. In addition, East Germany was added to the German sample upon reunification. Other nations have replicated particular modules without being ISSP members (e.g. Poland, in 1987, and Switzerland, in 1987 and 1993). See www.issp.org.

6 In all European Union Member Countries, for each Eurobarometer, samples are drawn among the national population, aged 15 and over. The regular sample size is 1000 respondents per country except the United Kingdom (1000 for Great Britain and 300 for Northern Ireland and Luxembourg (300 until the late eighties, subsequently 500 or 600). They have included Greece since Autumn 1980, Portugal and Spain since Autumn 1985, and the former German Democratic Republic from Autumn 1990 onwards (additional East German sample of 1000 respondents). In addition, an autonomous standard Eurobarometer on selected sets of questions was established in Norway (1000) in Autumn 1991 and in Finland (1000) in Spring 1993. Austria (1000) and Sweden (500) first joined in Autumn 1994. In Spring 1995, the complete survey series was expanded to the new European Union member countries Finland, Sweden and Austria. Iceland (600) first participated in Spring 2003. The EU also ran a Central and Eastern Eurobarometer (CEEB) survey between 1990 and 1997 with a sample size of about 1000 respondents per country - see Blanchflower (2001) for details. In October 2001, the European Commission launched a new series of surveys in the 13 countries that are applying for European Union membership under the heading Candidate Eurobarometer. The first such survey was carried out in Bulgaria, Cyprus, Czech Republic, Estonia, Hungary, Latvia, Lithuania, Malta, Poland, Romania, Slovakia, Slovenia, Turkey and in the southern part of Cyprus. 
capital. The self-employed work exceptionally long hours. The self-employed in general, and the most successful ones with employees - the job makers - in particular, report that, in comparison with those who do wage work they are less satisfied with the long hours they have to work. The self-employed are especially likely to report that they find their work stressful; they come home from work exhausted; that their job limits their family time; that they felt too tired after work to enjoy the things they would like to do in the home; that their partner/family gets fed up with the pressure of their job; that they had lost sleep over worry; felt unhappy and depressed; were constantly under strain and worked under a great deal of pressure. However, they appear to be satisfied in their lives, prefer work over leisure and feel they have free choice and control over their lives. The availability of new European data means that I am able to distinguish between the satisfaction levels of the most successful self-employed who have one or more employees the job makers - and the self-employed without any employed who have created a job only for themselves. The size of any effects for the self-employed with employees are generally more pronounced than for the self-employed with no employees. The patterns are very similar across countries. In section five I present my conclusions. More does not appear to be better!

\section{Literature Review ${ }^{7}$}

There has been a growing body of empirical work on entrepreneurship in general and selfemployment in particular. ${ }^{8}$ Microeconometric work includes Fuchs (1982), Borjas and Bronars (1989), Evans and Jovanovic (1989), Evans and Leighton (1989), Fairlie (1999), Fairlie and Meyer (1996, 1998), Reardon (1998), Lofstrom (2002), Bruce and Schuetze (2003) and Black et al (2001) for the United States; Rees and Shah (1986), Pickles and O'Farrell (1987), Blanchflower and Oswald (1990, 1998a), Blanchflower and Freeman (1994), Meager (1992), Taylor (1996), and Robson (1998a, 1998b) for the UK; DeWit and van Winden (1990) for the Netherlands; Alba-Ramirez (1994) and Carrasco (1999) for Spain; Bernhardt (1994), Schuetze (2000), Zhengxi et al (1999, 2000), Arai (1997), Lentz and Laband (1990), and Kuhn and Schuetze (2001) for Canada; Laferrere and McEntee (1995) for France; Vijverberg (1995) for Ghana; Vijverberg (1991) for the Cote d'Ivoire; Blau (1986) for Malaysia; Johnson (1985) for Tanzania; Blanchflower and Meyer (1994) and Kidd (1993) for Australia; Genda and Kambayashi (2002) for Japan; Kontos, M. (2003), Wagner, J. (2003) and Williams (2003) for Germany; Ozcan et al (2003) for Turkey; Lindh, T. and H. Ohlsson (1996, 1998), Hammarstedt (2001) for Sweden and Andersson and Wadensjö (2003) for Sweden and Denmark; Johansson (2000a, 2000b) and Kangasharju and Pekkala (2002) for Finland; Nziramasanga and Lee, (2001) for Zimbabwe; Harhoff, Stahl, and Waywood (1998), Pfeiffer and Pohlmeier (1992), and Georgellis and Wall (1999) on Germany; and Foti and Vivarelli (1994) for Italy. There are also several theoretical papers including Kihlstrom and Laffonte (1979), Kanbur (1982), Croate and Tennyson (1992), and Holmes and Schmitz (1990), plus a few papers that draw comparisons across countries such as Schuetze (1998) for Canada and the U.S., Blanchflower and Meyer (1994) for Australia and the U.S., Alba-Ramirez (1994) for Spain and the United States, and Blanchflower (2000) and Acs and Evans (1994) for many countries.

One possible impediment to entrepreneurship is lack of capital. In work based on U.S. micro

\footnotetext{
7 This is an updated version of the literature review presented in Blanchflower (2000).

8 For an earlier survey of the empirical literature on self-employment across countries see also Le (1999).
} 
data at the level of the individual, Evans and Leighton (1989), and Evans and Jovanovic (1989), have argued formally that entrepreneurs face liquidity constraints. The authors use the National Longitudinal Survey of Young Men for 1966-1981, and the Current Population Surveys for 1968-1987. The key test shows that, all else remaining equal, people with greater family assets are more likely to switch to self-employment from employment. This asset variable enters probit equations significantly and with a quadratic form. Although Evans and his collaborators draw the conclusion that capital and liquidity constraints bind, this claim is open to the objection that other interpretations of their correlation are feasible. One possibility, for example, is that inherently acquisitive individuals both start their own businesses and forego leisure to build up family assets. In this case, there would be a correlation between family assets and movement into self-employment even if capital constraints did not exist. A second possibility is that the correlation between family assets and the movement to self-employment arises because children tend to inherit family firms. Parker (2002) provides some much needed theory on whether banks ration enterprises.

Blanchflower and Oswald (1998a), find that the probability of self-employment depends positively upon whether the individual ever received an inheritance or gift. This emerges from British data, the National Child Development Study; a birth cohort of children born in March 1958 who have been followed for the whole of their lives. Second, when directly questioned in interview surveys, potential entrepreneurs say that raising capital is their principal problem. Third, the self-employed report higher levels of job and life satisfaction than employees. Fourth, psychological test scores play only a small role. Burke et al $(2000,2002)$ replicate the findings using the same data source. Work by Holtz-Eakin, Joulfaian and Rosen (1994a, 1994b), drew similar conclusions using different methods on U.S. data. The work of Black et al. (1996) for the UK, discovers an apparently powerful role for house prices (through its impact on equity withdrawal) in affecting the supply of small new firms. Cowling and Mitchell (1997), find a similar result. Again this is suggestive of capital constraints. Lindh and Ohlsson (1994) adopt the Blanchflower-Oswald procedure and provide complementary evidence for Sweden. Finally, Bernhardt (1994), in a study for Canada, using data from the 1981 Social Change in Canada Project also found evidence that capital constraints appear to bind.

Using the 1991 French Household Survey of Financial Assets, Laferrere and McEntee (1995), examined the determinants of self-employment using data on intergenerational transfers of wealth, education, informal human capital and a range of demographic variables. They also find evidence of the importance played by the family in the decision to enter self-employment. Intergenerational transfers of wealth, familial transfers of human capital and the structure of the family were found to be determining factors in the decision to move from wage work into entrepreneurship. Broussard et al. (2003) found that the self-employed in the USA have between .2 and .4 more children compared to the non-self-employed. The authors argue that having more children can increase the likelihood that an inside family member will be a good match at running the business. One might also think that the existence of family businesses, which are particularly prevalent in farming, is a further way to overcome the existence of capital constraints. Transfers of firms within families will help to preserve the status quo and will work against the interests of blacks in particular who do not have as strong a history of business ownership as indigenous whites. Analogously, Hout and Rosen (2000) found that the offspring of self-employed fathers are more likely than others to become self-employed and argued that the 
historically low rates of self-employment among African-Americans and Latinos may contribute to their low contemporary rates. Studies undertaken for the Australian and Canadian labor markets by Kidd (1993) and Bernhardt (1994) also reported that the availability of capital is a significant barrier to self-employment. Johansson (2000) in a study for Finland used a unique data file drawn from the Longitudinal Employment Statistics, compiled by Statistics Finland. It covers the years 1987-1995 and includes, in principle, every individual who has had a job in Finland during the period - it is the population. A sample of just over 100,000 workers aged 1865 was randomly selected and they were followed from 1987-1994. Johannsson's empirical strategy was to model the probability of an individual entering self-employment. The main result from the study was that a higher level of wealth significantly increased the probability that an individual made a transition from wage-employment to self-employment.

A continuing puzzle in the literature has been why the self-employment rate of black males is one third of that of white males and has remained roughly constant since 1910. Fairlie and Meyer (2000), rule out a number of explanations for the difference. They found that trends in demographic factors, including the Great Migration and the racial convergence in education levels "did not have large effects on the trend in the racial gap in self-employment" (page 662). They also found that an initial lack of business experience "cannot explain the current low levels of black self-employment". Further they found that "the lack of traditions in business enterprise among blacks that resulted from slavery cannot explain a substantial part of the current racial gap in self-employment" (page 664). Fairlie (1999) in a recent paper has shown that a considerable part of the explanation of the differences between the African-American and white selfemployment rate can be attributed to discrimination. Tim Bates (1989), finds strong supporting evidence that racial differences in levels of financial capital have significant effects upon racial patterns in business failure rates. Robert Fairlie (1998) found that the black exit rate from selfemployment is twice as high as that of whites. Fairlie and Meyer (1998) found that immigration had no statistically significant impact at all on black self-employment. In a subsequent paper Fairlie and Meyer (2004), found that self-employed immigrants did displace self-employed native non-blacks. They found that immigration has a large negative effect on the probability of self-employment among native non-blacks, although, surprisingly, they found that immigrants increase native self-employment earnings.

Blanchflower, Levine and Zimmerman (2004) found evidence that minority-owned firms are discriminated against in the market for credit. There is a market failure in the credit market - the commercial banks in the US appear to be the major source of the credit constraints faced by minorities. The data they use are drawn from a representative sample of small firms with less than 500 employees in the US in both 1993 and 1998. The data are especially relevant as they were collected by the regulator - the Board of Governors of the Federal Reserve System and the Small Business Administration. The main findings from the study were as follows.

1.1. Minority-owned firms were particularly likely to report that they did not apply for a loan over the preceding three years because they feared the loan would be denied.

1.2. When minority-owned firms did apply for a loan their loan requests were substantially more likely to be denied than other groups, even after accounting for differences in factors like size 
and credit history. A comparable loan filed by a firm owned by blacks is twice as likely to be denied than if the application was filed by a white owner.

1.3. No evidence of race differences was found with the use of credit cards. This is corroborative evidence that the results on loan applications are not being driven by unobserved variables. In contrast to a small business loan where the bank normally interviews the applicant, with credit cards the approval process is highly automated and the race of the applicant is normally unknown to the lending institution.

1.4. When minority-owned firms did receive a loan they would have to pay higher interest rates on the loan than was true of comparable white-owned firms. Blacks receive a double whammy even if they get through the tough hurdle of having their loans approved they would have to pay a one percentage point higher interest rate than if they had been white and filed the same loan application.

1.5. A greater share of minority-owned firms complained that the availability of credit was, or had been, the most important issue likely to confront the firm in the past, present and future.

1.6. There is no evidence that the level of discrimination in the market for credit has diminished during the 1990s.

There has been relatively little work on how institutional factors influence self-employment. Such work that has been conducted includes examining the role of minimum wage legislation (Blau, 1987), immigration policy (Borjas and Bronars, 1989), and retirement policies (Quinn, 1980). Studies by Long (1982), and Blau (1987), and more recently by Schuetze (1998), have considered the role of taxes. In an interesting study pooling individual level data for the U.S. and Canada from the Current Population Study and the Survey of Consumer Finances, respectively, Schuetze (1998), finds that increase in income taxes have large and positive effects on the male self-employment rate. He found that a 30 percent increase in taxes generated a rise of 0.9 to 2 percentage points rise in the male self-employment rate in Canada compared with a rise of 0.8 to 1.4 percentage point rise in the U.S. over 1994 levels.

A number of other studies have also considered the cyclical aspects of self-employment and in particular how movements of self-employment are correlated with movements in unemployment. Meager (1992), provides a useful summary of much of this work. Evans and Leighton (1989) found that white men who are unemployed are nearly twice as likely as wage workers to enter self-employment. Bogenhold and Staber (1991), also find evidence that unemployment and selfemployment are positively correlated. In Blanchflower and Oswald (1990), we found a strong negative relationship between regional unemployment and self-employment for the period 19831989 in the UK using a pooled cross-section time-series data set. In Blanchflower and Oswald (1998a), we confirmed this result, finding that the log of the county unemployment rate entered negatively in a cross-section self-employment probits for young people age 23 in 1981, and for the same people aged 33 in 1991. Taylor (1996), confirmed this result using data from the British Household Panel Study of 1991, showing that the probability of being self-employed rises when expected self-employment earnings increase relative to employee earnings, i.e., when unemployment is low. Acs and Evans (1994), found evidence from an analysis of a panel of 
countries that the unemployment rate entered negatively in a fixed effect and random effects formulation. However, Schuetze (1998), found that, for the U.S. and Canada that the elasticity of the male self-employment rate with respect to the unemployment rate was considerably smaller than he found for the effect from taxes discussed above. The elasticity of selfemployment associated with the unemployment rate is about 0.1 in both countries using 1994 figures. A decrease of 5 percentage points in the unemployment rate in the U.S. (about the same decline occurred from 1983-1989) leads to about a 1 percentage point decrease in selfemployment. Bruce and Schuetze (2003) find that, relative to continued wage employment, brief spells in self-employment do not increase-and probably actually reduce-average hourly earnings upon return to wage employment. They also find that those who experience selfemployment have difficulty returning to the wage sector. However, these consequences are small compared to similar experiences in unemployment. In Blanchflower (2000), I found that there is generally a negative relationship between the self-employment rate and the unemployment rate. It does seem then that there is some disagreement in the literature on whether high unemployment acts to discourage self-employment because of the lack of available opportunities or encourage it because of the lack of viable alternatives. In that paper I was unable to any evidence that increases in the self-employment rate raised the real growth rate of the economy; in fact there was even evidence of the opposite. More does not appear to be better.

In Blanchflower (2001) I found that on a variety of attitudinal measures, Eastern Europeans said they were less contented than their western European counterparts. The strongest support for the changes that have occurred in Eastern Europe is to be found among men, the young, the most educated, students, and the employed and particularly the self-employed. Support for market reforms was particularly low amongst the unemployed who were found to be particularly unhappy on two well-being measures.

There is, however, a good deal of agreement in the literature on the micro-economic correlates of self-employment (see Aronson, 1991), on this. It should be pointed out that most of this work is based on U.S. data and, as we shall see below, the results do not necessarily carry through elsewhere. Subject to that caveat it appears that self-employment rises with age, is higher amongst men than women and higher among whites than blacks. The least educated have the highest probability of being self-employed in Europe, however, as we will show below the reverse is the case in the US where increases in educational attainment are generally found to lead to increases in the probability of being self-employed. The more children in the family, the higher likelihood of (male) self-employment. Workers in agriculture, retailing, real estate and construction are especially likely to be self-employed.

\section{Self-employment rates by country}

Self-employment rates tend to vary a great deal across both countries and time. It is difficult to obtain comparable estimates by country because of differences in the way self-employment is measured (for a discussion see Blanchflower, 2000). The most definitive source of data is that provided by the OECD. ${ }^{9}$ Figure 1 provides detailed yearly plots for the 24 countries for which we have a long time run of data for the overall and non-agricultural rates - in all cases the former plot is above the latter because of the high rates of self-employment in agriculture everywhere. I

9 http://www1.oecd.org/scripts/cde/members/LFSDATAAuthenticate.asp 
do have some concerns about the reliability of these data: especially worrying are the unexplained big jumps between successive years for several countries - Germany, Finland, Portugal, Norway and Sweden are the most obvious examples. At this time we have no better source: in subsequent sections I turn to using more consistent micro-data obtained from comparable surveys taken across multiple countries. For ease of reference Table 1 provides estimates of the self-employment rates for selected years from 1956-2002. If data for the exact years are not available then those from the closest available year are reported. Table 1a provides overall results for both the agricultural and non-agricultural sectors while Table $1 \mathrm{~b}$ provides estimates for the non-agricultural sector. We exclude agriculture here as it is different - selfemployment rates have generally been high there and declining, a point we return to momentarily. A number of facts stand out from the table

2.1. There is considerable variation in self-employment (SE) rates across countries. The latest rates available, mostly in 2002, vary from a low of 5.9\% in Luxembourg to a high of $37.8 \%$ in Greece.

2.2. SE rates are generally higher in poorer countries such as Greece, Turkey, Mexico, Korea and Portugal.

2.3. SE rates appear to have declined over time in most countries. The major exception is the UK which has experienced growth from $7.7 \%$ in 1956 to $11.5 \%$ in 2002 . The Czech Republic has seen an increase over the short time frame since the fall of the Berlin wall.

2.4. Non-agricultural rates of SE are everywhere lower than the overall rates due to the high levels of SE in agriculture. Non-agricultural rates have increased in Australia, Belgium, the Czech Republic, Iceland, Ireland, Mexico, New Zealand, Poland, Portugal, Slovak Republic, Sweden and the UK.

Data for intervening years are also available so Table 2 examines further the issue of whether there have been declines in the self-employment rate over time. There are approximately 1000 observations across 30 countries over the period 1956-2002. Three separate regressions are run for each country with the dependent variable the overall SE rate, the non-agricultural rate and the agricultural rate. Included in each regression is a linear time trend and a constant only. The table reports whether the time trend is significant (positive $(+)$ or negative $(-)$ ) or not: a 0 implies that the coefficient on the time trend is insignificantly different from zero. Conclusions from this table are as follows.

2.5. There is a preponderance of negatives in the first column of Table 2 confirming the earlier findings from the means that overall self-employment rates are in decline in most countries except the UK and the Czech Republic. There is now evidence in this table that New Zealand has seen an increase.

2.6. There is evidence that non-agricultural rates have gone up significantly in thirteen countries - Australia, Finland, Eire, Iceland, Mexico, New Zealand, Poland, Portugal, Slovak Republic, Sweden, Spain and the UK. 
2.7. There is evidence that Non-agricultural rates have declined significantly in fourteen countries - Austria, Germany, Denmark, France, Greece, Hungary, Italy, Japan, Korea, Luxembourg, Netherlands, Norway, Turkey and the USA.

2.8. Agricultural rates increased significantly over time only in the Czech Republic, the UK, Greece, Hungary, Korea, Portugal and the Slovak Republic.

Table 3 reports a pooled cross-country regression using the data from Table 2. Results are provided overall, for non-agriculture and agriculture; equations include a time trend with and without a lagged dependent variable alongside a full set of country dummies. Overall the trend is down in all six columns, whether or not a lagged dependent variable is included. When the lag is in there, and it seems it should be given the very high t-statistics in all three columns, as might be expected, the magnitude of the country effects declines. Looking at columns 2 and 4, Greece, Italy, Korea, Mexico and Turkey have relatively large positive coefficients; Canada, Denmark, Luxembourg, Norway and Sweden have the largest negative coefficients.

It is natural to look a little more closely at micro-data at the level of the individual to determine what characteristics the self-employed possess. To set the scene, Table 4a presents the simplest kind of self-employment probit equation across member countries of the European Union. Weights are imposed so that the results are representative of the EU as a whole. The data file used is the Mannheim Eurobarometer Trend File, 1970-1999 (ICPSR\#3384) which combines seventy different Eurobarometer Surveys into comparable format. Data on self-employment are only available for the years 1975-1999. I report estimated derivatives from these models that can be interpreted as the effect on the probability of being self-employed of an infinitesimal change in each independent continuous variable and the discrete change in the probability for dummy variables. Here the dependent variable is set to one if the person reports themselves as selfemployed and set to zero if they are a worker: agricultural workers are excluded. The sample size is approximately 385,000 people from each of the member countries of the EU: separate results are also reported for Northern Ireland and East and West Germany. The omitted base category is France. The first equation includes country dummies and no personal controls along with a time trend that has a significant negative coefficient. When personal controls are included the significance of the time trend disappears. Self-employment is higher for men and for those with less education. The probability of being self-employed in the EU rises with age and reaches a maximum at age 76 . The country dummies provide a snapshot view of the international pattern of self-employment. Greece and Italy are at the top of the rankings, for instance, while the Netherlands and Denmark are at the bottom. The probability of being self-employed is lower among highly educated workers. The t-statistic on years of schooling is well-determined at 8.99 in the first column of Table 2. Compositional variables on full-time/part-time matter. As is known, a variable for being male enters strongly positively in a self-employment equation. Age also enters positively, with a small standard error.

Table $4 \mathrm{~b}$ provides comparable evidence from the United States using data from the Outgoing Rotation Group (ORG) files of the Current Population Survey. This Table is taken from Blanchflower and Wainwright (2004). Sample size is large: there are a total of over 4 million data points. Separate equations are reported for the period 1979-1991 and for 1992-2002. The reason for this is there was a sample redesign in 1992 and a number of the equations were 
changed - in particular the questions on schooling. Controls include a full set of state, year and industry dummies along with controls for gender, schooling and race. A full set of industry dummies are included but the three largest industry dummies are reported - Construction, Repair Services and Personal Services. The coefficients that are reported are in relation to the excluded category Agricultural Services which is the industry with the highest rate of self-employment; hence all of the other industry dummies have larger negative coefficients. Column 3 includes controls for country of origin if the individual was not born in the US: column 4 is restricted to the US born. The sample for the final two columns is for 1994-2002 as these are the only years where immigration status information is available. The main findings are.

2.9. Self-employment is higher among men than women.

2.10. The gender gap has narrowed over time from $4.7 \%$ in the first period to $2.7 \%$ in the second.

2.11. Minorities have lower self-employment rates than whites - blacks for example have rates 4.5 percentage points lower than whites in the second period while Hispanics are 3.7 percentage points lower.

2.12. The gap between black and white rates have remained constant whereas the gap for Hispanics has widened from $2.9 \%$ to $3.7 \%$.

2.13. The race effects are broadly similar when the sample excludes individuals born outside the United States in column 4.

2.14. As in the EU the probability of being self-employed rises with age to a maximum and then declines. In the first period it reaches a maximum at age 61 and at age 54 in the later period, which is a lot lower than was found for the EU.

2.15. Self-employment is especially prevalent in Construction, Repair Services, Personal Services and Agriculture.

2.16. In contrast to the EU, the probability of being self-employed is related positively to an individual's schooling. In column 1 years of schooling enters positively. In the second column years of schooling is replaced with a set of fifteen levels of education dummies, which also show the same result. The excluded category is 'Less than first grade'.

\begin{tabular}{|l|l|}
\hline Less than 1st grade & 0 \\
\hline $1^{\text {st }}-4^{\text {th }}$ grade & .0076 \\
\hline $5^{\text {th }}$ or $6^{\text {th }}$ & .0499 \\
\hline $7^{\text {th }}$ or $8^{\text {th }}$ & .1041 \\
\hline $9^{\text {th }}$ & .1016 \\
\hline $10^{\text {th }}$ & .1045 \\
\hline $11^{\text {th }}$ & .0981 \\
\hline $12^{\text {th }}$ grade no diploma & .1034 \\
\hline High school graduate, diploma or & .1002 \\
\hline
\end{tabular}




\begin{tabular}{|l|l|}
\hline GED & .1386 \\
\hline Some college but no degree & .1498 \\
\hline $\begin{array}{l}\text { Associate degree -- } \\
\text { occupational/vocational }\end{array}$ & .1596 \\
\hline $\begin{array}{l}\text { Associate degree -- academic } \\
\text { program }\end{array}$ & .1959 \\
\hline Bachelor's degree & .2250 \\
\hline Master's degree & .5292 \\
\hline Professional school degree & .4195 \\
\hline Doctorate degree & \\
\hline
\end{tabular}

2.17. There is a downward trend in self-employment in the USA. This can be seen from the two sets of year dummies included in both equation 1 and 2 that are shown below. Year dummies are included rather than a time trend simply because of the size of the data files concerned and the fact that there are not consistent education controls available through time. The left side below takes the year dummies from column 1 of Table $4 \mathrm{~b}$ and the right side takes the year dummies from column 2 of the Table. In both cases there is a steady decline in the coefficients. The effect is more pronounced in the later period. Of course, the two sets of data should be considered as cumulative; 1992 is simply rescaled to zero and then later years compared to it. 1992 itself is likely more than three percentage points lower than the 1979 rate.

\begin{tabular}{|lcc|lrr|}
\hline Year & Coefficient & T-statistic & Year & Coefficient & T-statistic \\
1979 & 0 & & 1992 & 0 & \\
1980 & .0010 & 1.39 & 1993 & -.0007 & 0.94 \\
1981 & .0013 & 1.76 & 1994 & .0044 & 5.43 \\
1982 & .0010 & 1.40 & 1995 & .0003 & 0.41 \\
1983 & .0026 & 3.57 & 1996 & -.0065 & 7.97 \\
1984 & .0029 & 3.91 & 1997 & -.0059 & 7.31 \\
1985 & .0003 & 0.48 & 1998 & -.0095 & 11.88 \\
1986 & -.0009 & 1.23 & 1999 & -.0125 & 15.68 \\
1987 & -.0005 & 0.74 & 2000 & -.0156 & 19.85 \\
1988 & -.0007 & 1.06 & 2001 & -.0191 & 25.03 \\
1989 & -.0023 & 3.22 & 2002 & -.0201 & 27.07 \\
1990 & -.0024 & 3.36 & & & \\
1991 & -.0033 & 4.61 & & & \\
\hline
\end{tabular}

There is a good deal of evidence that the trend in self-employment is downward in many OECD countries. Evidence from a series of GDP growth equations presented in Blanchflower (2000) did not suggest that the self-employment rate increased the real growth rate of the economy; in fact there was even evidence of the opposite. I have seen no convincing evidence of any kind in the literature that either increasing the proportion of the workforce that is self-employed, or having a high level of self-employment produces any positive macroeconomic benefits. Such evidence that does exist suggests quite the reverse. More is not better.

2.18. Governments on the other hand frequently see self-employment as a route out of poverty and disadvantage and for this reason offer aid and assistance for small businesses. The 
justification for these actions are usually that this will help promote invention and innovation and thus create new jobs; new firms may also raise the degree of competition in the product market bringing gains to consumers; greater self-employment may also go along with increased selfreliance and well being. Unfortunately economists have little evidence on whether these hypothetical benefits exist in practice. Even the widely held view, best expressed in Birch (1979), that small firms disproportionately are the creators of jobs has been challenged by Davis, Haltiwanger and Schuh (1996) who have undertaken the most careful empirical analysis of the job creation process to date. They argue persuasively that "conventional wisdom about the job creating powers of small businesses rests on statistical fallacies and misleading interpretations of the data" (1996, p.57). Indeed, they go on to conclude the following.

"It is true that small businesses create jobs in disproportionate numbers. That is gross job creation rates are substantially higher for smaller plants and firms. But because gross job destruction rates are also substantially higher for smaller plants and firms, they destroy jobs in disproportionate numbers. We found no strong systematic relationship between employer size and net job growth rates....Finally, and in contrast to the lack of a clear-cut relationship between employer size and job growth,...(we found)..clear evidence that large employers offer greater job durability" (1996, p.170).

Despite the lack of evidence of the benefits of having a larger small business sector and/or having a higher proportion of the workforce self-employed many governments around the world provide subsidies to individuals set-up and to remain in business. In Australia, Britain and France, for example, government programs provide transfer payments to the unemployed while they attempt to start businesses. ${ }^{10}$ Many countries, including the UK and the United States, have government programs to provide loans to small businesses, and even exempt small businesses from certain regulations and taxes. In the U.S. similar programs are being started for unemployment insurance and welfare recipients.

Kosanovich et al (2001) report that programs to help the unemployed move into selfemployment are highly effective in raising the self-employment rate of participants, although it remains unclear how cost effective the programs are. Between 1995 and 1999 seven states Delaware, Maine, Maryland, New Jersey, New York, Oregon, and Pennsylvania participated in a Self-Employment Assistance Program (SEA). To participate in an SEA program, Unemployment Insurance (UI) claimants must pass through a profiling process that was designed to assess the likelihood of their reemployment within the 26 weeks of benefit eligibility or, conversely, the likelihood of their exhaustion of benefits prior to reemployment. By statute, SEA programs may not serve more than $5 \%$ of a state's UI claimants. Only New York has ever included more than $1 \%$ of its UI claimants in its SEA program. Kosanovich et al (2001) in a study undertaken on behalf of the U.S. Department of Labor Office of Workforce Security, surveyed 1176 participants in the SEA programs in the states of Maine, New Jersey and New York and found that the respondents achieved high rates of self-employment. Compared to eligible non-participants, individuals who participated in the SEA program in these states were 19 times more likely to have been self-employed at any time post-unemployment. For

10 See Kelly et al (2002) and Bendick and Egan (1987) 
participants 25-36 months from initial program enrollment, 58\% in New York and 60\% in New Jersey were either self-employed or both self-employed and wage/salary employed. In Maine, over $40 \%$ of participants were either self-employed or both self-employed and wage/salary employed at 25-36 months since their program enrollment. higher rates of reemployment in any position, whether self-employed or wage/salary employed, than non-participants. The study found that program participants were four times more likely than non-participants to have obtained employment of any kind (either wage/salary or self-employment). These programs appear to be effective in helping the unemployed move into self-employment and stay there; but there is no evidence that suggests they have any impact on macroeconomic performance.

2.19. Black, Holtz-Eakin and Rosenthal (2001) show that there is considerable regional dispersion in self-employment rates. Below are self-employment rates (\%) they constructed (2001 Table 1) for males, 25 to 64 Years Olds taken from the 1990 Census of Population.

\begin{tabular}{|l|r|r|r|r|c|}
\hline Region & All & White & Black & Hispanic & Asians \\
\hline Northeast & 9.9 & 10.7 & 3.9 & 4.2 & 6.2 \\
\hline Middle Atlantic & 11.2 & 11.9 & 3.8 & 6.1 & 12.2 \\
\hline East-North Central & 10.5 & 11.1 & 3.2 & 5.5 & 10.1 \\
\hline West-North Central & 11.7 & 12.1 & 3.9 & 6.2 & 7.8 \\
\hline South Atlantic & 11.7 & 13.1 & 4.9 & 8.9 & 13.7 \\
\hline East-South Central & 10.5 & 11.9 & 4.0 & 11.2 & 12.2 \\
\hline West-South Central & 12.2 & 14.6 & 4.7 & 7.6 & 11.4 \\
\hline Mountain & 12.5 & 14.1 & 4.3 & 6.6 & 10.7 \\
\hline Pacific & 12.7 & 14.5 & 5.5 & 6.9 & 11.2 \\
\hline United States & 11.4 & 12.7 & 4.3 & 6.8 & 11.1 \\
\hline
\end{tabular}

The authors show that the variation of self-employment rates across areas cannot be attributed to differences among the metropolitan areas in the individual attributes - age, education, immigrant status, marital status, and so on-of their populations. Neither can it be explained simply on the basis of location - there are not simply good places and bad places for the self-employed of all races. Instead, they find that variation in self-employment and earnings is positively linked to minority-specific measures of economic scale - the purchasing power that minorities bring to the metropolitan-area market. This result is robust to a variety of specifications and controls for various alternative MSA attributes that might otherwise account for the finding, including minority and white MSA unemployment rates and the degree of MSA minority segregation. Our work provides support for the idea that the economic scale of the minority market affects the ability of metropolitan areas to sustain minority entrepreneurs. Moreover, the authors argue that this conclusion "is consistent with models of self- employment in which consumer discrimination against minority entrepreneurs dampens minority self-employment opportunities" (2001, p.270). Their findings also appear to be consistent with a model where discrimination comes from other sources including the banks or even trade unions (see Ashenfelter, 1972).

The likelihood is that both spatial variation in self-employment and the return to selfemployment among minorities will be impacted by the existence of affirmative action programs run by most large local municipalities - examples are San Francisco, New York, Chicago, Baltimore, St. Louis and Jacksonville, Florida. There is a growing body of evidence that does 
exist that the affirmative action programs that have been introduced in the US to counter discrimination against minorities and women-owned firms (MWBEs) especially in US construction do have large micro-economic effects. These programs fall into two types a) Federal Disadvantaged Business Enterprise (DBE) Program which sets a goal of $10 \%$ of spending to DBEs for entities that take federal dollars b) city, state and local governments own programs. Blanchflower and Wainwright (2004) provide evidence from a series of natural experiments that show that once the programs are removed - which often occurs by court injunction following the Supreme Court's finding in the case of Croson vs, City of Richmond in 1989 - utilization of MWBEs drops precipitously. ${ }^{11}$ These programs appear to be effective in countering the effects of discrimination against MWBEs; there is no evidence that they have any impact on macroeconomic performance.

2.20. There is considerable variation in the self-employment rate of immigrants. Blanchflower and Wainwright took the significant country dummies from Table $4 \mathrm{~b}$, translated them into percentage differences by taking antilogs and deducting one, because the dependent variable is in logs. Their findings are presented below - they are all in comparison to the United States. Countries with coefficients that are not significantly different from the US are not reported. Individuals from Syria, Greece, Israel and Lebanon have high self-employment rates; those from Laos, Mexico, the Philippines and Guatemala have low rates.

\begin{tabular}{|c|c|c|c|c|c|}
\hline Syria & $9.3 \%$ & Ethiopia & $2.3 \%$ & Other & $0.7 \%$ \\
\hline Greece & $6.0 \%$ & Palestine & $2.1 \%$ & Russia & $-0.5 \%$ \\
\hline Israel & $5.6 \%$ & Malaysia & $2.0 \%$ & Vietnam & $-0.5 \%$ \\
\hline Lebanon & $5.1 \%$ & Turkey & $2.0 \%$ & Puerto Rico & $-0.6 \%$ \\
\hline Bermuda & $4.8 \%$ & Asia & $2.0 \%$ & Nicaragua & $-0.6 \%$ \\
\hline Uruguay & $4.6 \%$ & Belgium & $1.7 \%$ & Haiti & $-0.6 \%$ \\
\hline Grenada & $4.1 \%$ & Pakistan & $1.7 \%$ & Guyana & $-0.7 \%$ \\
\hline North Africa & $3.5 \%$ & South America & $1.7 \%$ & El Salvador & $-0.8 \%$ \\
\hline Kenya & $3.4 \%$ & Brazil & $1.5 \%$ & Cambodia & $-0.9 \%$ \\
\hline Iraq & $3.2 \%$ & Africa & $1.5 \%$ & Honduras & $-0.9 \%$ \\
\hline South Korea & $3.0 \%$ & Europe & $1.4 \%$ & Mexico & $-1.0 \%$ \\
\hline Nigeria & $2.9 \%$ & Austria & $1.3 \%$ & Laos & $-1.1 \%$ \\
\hline Philippines & $2.8 \%$ & India & $1.0 \%$ & Guatemala & $-1.1 \%$ \\
\hline Taiwan & $2.8 \%$ & Portugal & $0.9 \%$ & Caribbean & $-1.1 \%$ \\
\hline South Africa & $2.6 \%$ & Canada & $0.9 \%$ & Philippines & $-1.2 \%$ \\
\hline
\end{tabular}

${ }^{11}$ In a series of recent court decisions where I was the defendant's expert the constitutionality of the federal DBE program has been upheld both at the level of the district court and the $8^{\text {th }}$ Circuit Court of Appeals (Sherbrooke Turf vs, State of Minnesota DOT; Gross Seed vs. State of Nebraska DOT). Following Croson there were many lower court decisions in the 1990s which declared state and local programs to be unconstitutional. A recent decision by the $10^{\text {th }}$ Circuit Court of Appeals in the case of Concrete Works of Colorado Inc. vs. City of Denver, where I was also a testifying expert for the defendant, overturned the District Court's ruling that the program was unconstitutional. The Appeals Court decision was itself appealed to the US Supreme Court which refused to grant a writ of certiorari, despite the fact that the case had been distributed for conference six times. Unusually, Justice Antonin Scalia and Chief Justice William Rehnquist issued a dissenting opinion: http://www.supremecourtus.gov/opinions/03relatingtoorders.html. This important decision suggests that these programs may get a new lease of life. 


\begin{tabular}{|ll|ll|ll|}
\hline Italy & $2.5 \%$ & Cuba & $0.9 \%$ & Pacific Islands & $-1.4 \%$ \\
Iran & $2.5 \%$ & France & $0.7 \%$ & & \\
Argentina & $2.3 \%$ & England & $0.3 \%$ & & \\
\hline
\end{tabular}

Lofstrom (2002) uses data from the 1980 and 1990 U.S. Censuses to study labor market assimilation of self-employed immigrants. Separate earnings functions for the self-employed and wage/salary workers are estimated. Self-employed immigrants were found to do substantially better in the labor market than wage/salary immigrants. Earnings of self-employed immigrants re predicted to converge with natives' wage/salary earnings at about age 30 and natives' self-employed earnings at about age 40. Including the self-employed in the sample reduces the immigrant-native earnings gap by, on average, 14\%. Bates (1999) argues that selfemployment is often a form of underemployment among Asian immigrants. Crowding of Asian immigrants into traditional fields such as small-scale retailing, Bates argues, has often been interpreted as evidence of success and/or expanding. In light of the low returns earned by Asian immigrants in traditional businesses and the observed outflow from these fields over time, Bates argues that such crowding is rooted in "blocked-mobility considerations" (p. 181).

2.21. Individuals emigrating to the US from most member countries of both the EU and the OECD have higher self-employment rates than the US born. The main exceptions are Australia, Germany, Denmark, Finland, France, Ireland, Japan, Luxembourg, Norway, Sweden, Switzerland. Mexico has a significantly lower self-employment rate.

As we noted above there is a literature in the US explaining differences between the AfricanAmerican and white self-employment see for example Fairlie (1999), Bates (1989), Fairlie and Meyer $(1998,2004)$. There is also a literature suggesting that there are considerable differences in self-employment rates of immigrants based on their country of origin. Yuengert (1995) finds that immigrants to the USA from countries with higher self-employment rates are more likely to enter self-employment. In a follow-up analysis though Fairlie and Meyer (1996) found that this effect was not statistically significant. Also, he finds that immigrants are more concentrated in high tax states where self-employment with its greater opportunities for tax avoidance is more prevalent. In contrast to claims made in Borjas (1986), Yuengert finds no evidence that selfemployment rates are higher in cities with higher concentrations of immigrants.

Clark and Drinkwater (2000) in their study of self-employment among ethnic minorities in England and Wales found that ethnic minorities who live in areas which have a high percentage of their own group are less likely to be self-employed. They found that those with poor language skills and more recent immigrants had lower self-employment probabilities. Borooah and Hart (1999) used data from the British 1991 Census to examine why so many Indians, but so few black Caribbeans, in Britain are self-employed? Over $20 \%$ of economically active Indian males, but only $8 \%$ of economically active black Caribbean males, were self-employed. The reluctance of black men to become self-employed was, as this study suggested, due to two factors. First, they were, relative to whites and Indians, "ethnically disinclined" to enter business - this stunted their desire to be self-employed. Second, they did not possess, relative to whites and Indians, the attributes that were positively related to entering business - this impaired their ability to be selfemployed. The authors estimated that $58 \%$ of the observed lack (relative to Indians) of selfemployed black males was due to ethnic disinclination and $42 \%$ was due to attribute 
disadvantage. Of course this result begs the question of why Caribbean men were disinclined to be self-employed. Clark and Drinkwater (2000) also reported that, based on the 1991 Census of Population, self-employment rates for blacks in England and Wales were 5.8\% compared with $26.6 \%$ for Chinese and $12.3 \%$ for whites and $14.6 \%$ for non-whites. ${ }^{12}$ In contrast, in a study for Australia Kidd (1993) found that self-employment rates of the Australian born sample was $21.3 \%$ compared with $19.9 \%$ for migrants. Migrant self-employment rates were higher for individuals from non-English speaking (NES) countries $(22.0 \%)$ than from English speaking (ES) countries $(17.2 \%)$.

In a recent paper Andersson and Wadensjö, (2003) examined how self-employed immigrants had assimilated in Denmark and Sweden. They reported that immigrants self-employment rates in both countries were above those of the indigenous populations. In 1999, according to the authors, $4.1 \%$ of Swedish workers are self-employed compared to $6.4 \%$ in Denmark. These numbers are well below the OECD numbers reported in Table 1a of $9.5 \%$ and $8.3 \%$ respectively, for which I have no explanation. The self-employed in both Sweden and Denmark are concentrated in construction $(9.2 \%$ and $9.9 \%$ respectively); retailing $(12.7 \%$ and $18.1 \%)$ and real estate and rental services (12.9\% and $16.4 \%)$. Holding constant a variety of characteristics including schooling, age and gender Andersson and Wadensjö find that non-Western immigrants in both Denmark and Sweden are over-represented among the self-employed. They also found self-employed immigrants had lower incomes than immigrant employees. The differences are large, especially in Sweden. They concluded that immigrants in the two countries were becoming self-employed because they had difficulties obtaining wage employment.

\section{3. "Who wants to be self-employed"}

It is sometimes argued that nations differ in their underlying entrepreneurial spirit. The United States, in particular, is often singled out as a country with an inherently large number of people who are keen to start firms. Europe, it is sometimes asserted, lacks entrepreneurial individuals. While some politicians argue that Eastern Europe is in particular need of people who wish to run their own businesses, there is especially little information about the potential supply of entrepreneurs in that region of the world. Few economists have attempted to measure entrepreneurial spirit across countries. In Blanchflower, Oswald and Stutzer (202) we created an international league table of what might be thought of as the simplest measure of entrepreneurial drive. The paper measured entrepreneurial spirit by using the question:

"Suppose you were working and could choose between different kinds of jobs. Which would you prefer: being an employee or being self-employed?"

It is possible to think of many objections to this wording (from an economist's point of view it is vague on the constraints under which people are assumed to make their hypothetical choice), but it has the merit of simplicity. Moreover, because the wording is chosen deliberately to be consistent across countries, and our concern is to produce international comparisons, some of the question's drawbacks are reduced. If there are biases in the question's wording, those biases

\footnotetext{
${ }^{12}$ Using data from the Fourth National Survey of Ethnic Minorities conducted in 1993/4 Clark and Drinkwater found self-employment rates to be especially high, among both men and women, for Pakistanis, Indians and African Asians.
} 
may be similar across nations and thus still give useful cross-country information. The question was asked in an International Social Survey Programme data set. Information on more than twenty countries is available over a period spanning 1997 and 1998. For the analysis reported here, the sample size is approximately 25,000 individuals across 23 nations. Blanchflower (2000) and OECD (2000) look at related international self-employment statistics for OECD countries. But information on self-employment preferences in the 1990s has until now been sparse.

Table 5 contains the mean responses by country. To fix ideas, it is clear that an economist would not expect to find a large proportion of people answering in favor of self-employment. The vast majority of workers (almost nine out of ten, in most nations) in the industrial countries are conventional employees: they draw a pay check from a firm that someone else began. There is one small exception. In heavily agricultural sectors, and nations, the numbers of self-employed individuals tend to be higher; but the western democracies now have only tiny percentages of their population in agriculture. Moreover, the western nations have sophisticated banking systems, stock markets, and networks of venture capitalists. On the face of it there are many opportunities to borrow to back a good idea for a business start-up. At the turn of the $21^{\text {st }}$ century, therefore, an economist would not expect many of those who covet a chance to be selfemployed to be thwarted in that wish. However, the patterns in the answers are not what would have been predicted. There are apparently many frustrated entrepreneurs.

First, Table 5 reveals that there is a strikingly large latent desire to be in charge of one's own business. Even in countries at the bottom of the table, a quarter of the population say they would prefer to be self-employed. This compares to an actual proportion of self-employed people in most countries of around $10 \%-15 \%$ of the labor force. It is interesting to wonder why so few individuals manage to translate their preferences into action. Lack of start-up capital may be one explanation, and we return to that possibility later.

Objections are certainly possible. These subjects are asked a hypothetical question, in an unrealistic setting, and their answers may therefore be unrepresentative of the truth in a practical or implementable sense. The harshest of critics might argue that one could imagine a question 'if you were working and could choose between different kinds of jobs, would you prefer to be in your current job or be a top soccer player?', and that the answers to this might also be highly positive and yet not tell us very much except that people would like to earn as much as David Beckham. There is probably something to this criticism. Nevertheless, our aim is to capture the inherent level of entrepreneurial interest, not merely the level that is currently converted into activity. It would be extreme to view these survey answers as containing no useful food for thought. Moreover, while winning Wimbledon is beyond the scope of almost anyone, it is not clear that the same can be said of being self-employed. Almost anyone could be self-employed if they wished (perhaps on a low income); that is not true of the tennis question. And as the same question is asked everywhere, the relative responses should be meaningful.

The most compelling case, however, emerges from the structure of the answers. The numbers in Table 5 are so large, and information in the area sufficiently sparse, that we think it unwise to disregard answers of this type. In the late 1990s, in these countries, the data suggest that there is considerable interest in the idea of being self-employed. Second, and intriguingly, there is 
marked variation by nation. The proportions of people who favor self-employment vary from $80 \%$ to less than $30 \%$. Poland, Portugal and the USA top the league table. It appears that approximately three-quarters of these nations' citizens would like to manage their own business rather than work for a company as a regular employee. These proportions seem extraordinarily large, but we simply report them. Bottom of the league table of latent entrepreneurship come Russia, Denmark and Norway; Sweden is close to the bottom of the rankings. In these nations, roughly $30 \%$ of citizens say they are interested in being self-employed. Three developing countries are in the data set but, because of their reliance on agriculture, we choose not to include the numbers. They are Bangladesh, Cyprus and the Philippines. Self-employment and expressed desire for it are both high in the three countries, but we are not confident that it is possible to make valid comparisons with the more heavily industrial nations in the rest of the sample.

Table 6 contains information that would have been less easily anticipated. It estimates for men and women, from a sample of employees, the probability of an individual saying they would prefer to be self-employed rather than work for somebody else. First, age now enters Table 3's probit equation strongly negatively. In other words it has the opposite sign from that for age in the being-self-employed equation of Tables $4 \mathrm{a}$ for the EU and $4 \mathrm{~b}$ for the USA. This means that, despite the fact that older people are more likely to be self-employed, it is younger people who say they would prefer to be self-employed. A potential explanation is a kind of dynamic one. As they age, people simply flow into self-employment. Hence those who say when young that this is their aim gradually achieve that aim. But this cannot account for the much larger numbers asserting that self-employment is desirable relative to the small numbers who end up as selfemployed. Second, the structure of the country dummies is not identical to that for actual selfemployment in the previous table. As in the raw cross-tabulations of Table 5, Denmark and Norway are low in the implied dummy-variable ranking of Table 6. Poland and Portugal are again high: Sweden and Russia are also low. The notable feature is the contrast between age in Table 5 and in Tables $4 \mathrm{a}$ and $4 \mathrm{~b}$. Huge numbers of young workers in these industrial countries would prefer self-employment (or at least claim that they would). We know this from the fact that for the young the average numbers in Table 5 are an understatement -- as they are for the full sample and the age coefficient in the regression is negative -- of the amount of desire to be entrepreneurial.

Our results cannot be definitive because they rely on what people say they want. Yet they seem suggestive - leaving it natural to think that in these nations there may be a currently unexploited supply of entrepreneurial individuals. Young people are apparently particularly constrained to be workers rather than run their own businesses. If age entered with a zero coefficient in Table 6 , we could conclude that entrepreneurship choice was unconstrained by a person's age. A zero would signify that older workers preferred self-employment neither more nor less than the young. But that is not what the data show. As a person becomes older it becomes easier to break into entrepreneurship.

4. Are People Simply Mistaken to Prefer the Idea of Self-Employment?

Some economists might reason in the following way. One possible explanation for the high numbers in Tables 5 and 6 is that people are simply mistaken. Perhaps they have an unrealistically rosy view of what it is like to be running one's own business rather than have the comparative security of being an employee. One reason economists are often wary of subjective 
data is because people are sometimes thought to be unable to judge what will be in their own interest. $^{13}$

But Table 7 provides counter evidence. It shows, using the General Social Surveys (GSS) for the USA from 1972-2002 along with a recent sweep of the Eurobarometer Surveys (EBS) \#54.2, January-February, 2001 (ICPSR\#3211), that feelings of job satisfaction are higher among the self-employed. Both surveys use somewhat different responses to a similar question on job satisfaction. In the GSS respondents were asked 'On the whole, how satisfied are you with the work you do--would you say you are very satisfied, moderately satisfied, a little dissatisfied, or very dissatisfied?' and the distribution of responses for employees and the self-employed were as follows

\begin{tabular}{|l|c|c|}
\hline & Employees & Self-employed \\
\hline Very dissatisfied & $3.8 \%$ & $2.0 \%$ \\
\hline A little dissatisfied & $10.3 \%$ & $5.8 \%$ \\
\hline Moderately satisfied & $39.9 \%$ & $29.8 \%$ \\
\hline Very satisfied & $45.9 \%$ & $62.5 \%$ \\
\hline
\end{tabular}

In the EBS survey respondents were asked "on the whole, how satisfied are you with your current job or business? Please use the following scale from 1 to 10, where '1' means that you are not at all satisfied and '10' means that you are totally satisfied'. The average scores by country for employees and the self-employed were as follows.

\begin{tabular}{|l|c|c|}
\hline & Employees & Self-employed \\
\hline Austria & 7.75 & 7.58 \\
\hline Belgium & 7.66 & 7.94 \\
\hline Denmark & 8.03 & 8.60 \\
\hline East Germany & 7.37 & 8.77 \\
\hline Finland & 7.49 & 7.47 \\
\hline France & 7.15 & 7.33 \\
\hline Great Britain & 6.92 & 8.04 \\
\hline Greece & 6.65 & 5.68 \\
\hline Ireland & 7.51 & 7.82 \\
\hline Italy & 6.90 & 7.35 \\
\hline Netherlands & 7.41 & 7.72 \\
\hline Northern Ireland & 7.37 & 8.25 \\
\hline Portugal & 6.47 & 6.87 \\
\hline Spain & 6.88 & 7.53 \\
\hline Sweden & 7.38 & 8.43 \\
\hline
\end{tabular}

13 Bruno Frey in private communication suggested that people do make mistakes and are not always able to judge how much utility will be produced by goods and activites in the future. But, he points out, such a view is inconsistent with traditional economics. In strict neoclassics, people may make mistakes but correct them very quickly, so that in equilibrium one can assume that people maximize their utility. One of the fundamental premises of neoclassic, of course, is that people know well what they want and this underlies the whole neoclassical welfare economics. See Frey and Stutzer (2003) for more on this. 


\begin{tabular}{|l|l|l|}
\hline West Germany & 7.69 & 8.24 \\
\hline EU weighted average & 7.18 & 7.48 \\
\hline
\end{tabular}

In all but three countries - Austria, Greece and Finland - the self-employed report higher levels of job satisfaction than employees. Note also that there are differences and similarities in the pattern of the coefficients in the first two equations in Table 7 - in the US women are more satisfied than men but in Europe there is no gender difference. As we shall see below there is evidence from an earlier EBS sweep of a similar result to the US with women more satisfied than men. Both in the US and Europe, workers with higher levels of schooling are more satisfied. Job satisfaction is U-shaped in the USA in age reaching a maximum at age 61 but rises linearly with age in Europe; the age squared term was never significant and hence was omitted. Note that in the US blacks and other races are less happy at work than whites: the negative time trend implies that job satisfaction in the US has been declining over time (See Blanchflower and Oswald 1999 on this). Blacks are also found to be less happy with their lives in general (see Blanchflower and Oswald, 2004). An obvious interpretation for such a finding is discrimination.

In Blanchflower and Oswald (1999) a range of job characteristics were introduced in a series of job satisfaction equations using other EBS data files. ${ }^{14}$ Workers like to work independently and in workplaces with high pay and good chances of advancement. They also like to 'help people' and to work in healthy rather than unhealthy conditions. The result that people enjoy independence is well-known to psychology researchers. It is sometimes referred to as an example of the 'locus of control' hypothesis. Spector et al (2001) is a recent paper looking at a similarly large range of nations. Having a secure job increases job satisfaction: the easier it is to find a similar job the higher is satisfaction. We also found evidence for the positive impact of job security on job satisfaction in the US. Evidence was also found in that paper that job satisfaction is greater in quiet workplaces, ones with no gaseous vapors, ones where workers say 'no painful or tiring positions', where employees control the equipment, their work pace, where they do not have to carry move loads or work at high speed. Working at home appears to be associated with raised satisfaction for women but not men. The ability to control the temperature and ventilation is correlated with satisfaction. Employees who identify a health and safety risk at their workplace are much more likely to say they are dissatisfied. Unsurprisingly, women appear to value equal opportunities at work. We found no significant evidence that the gender of one's boss has an effect on job satisfaction for either men or women. Even when all these job characteristics were controlled for, the self-employed still reported higher levels of job satisfaction than the employed.

Table 7 also provides recent evidence from Europe on other aspects of the work environment. ${ }^{15}$ In the final five columns of the table male were less satisfied than females and satisfaction increased with age and years of schooling. The pattern of the country coefficients is similar across columns 2-7 with Greece having the largest negative coefficient in all columns and

\footnotetext{
14 See also Blanchflower and Oswald (2000)

${ }^{15}$ Workers were asked to use the same scale as discussed above for job satisfaction in response to each of the following questions. 1) And how satisfied are you with your current job or business in terms of earnings? 2) And in terms of job security? 3) And in terms of the type of work you do? 4) And in terms of the number of hours you work? 5) And in terms of the time it takes to travel to work?
} 
Denmark the largest positive in all cases except in relation to pay. In comparison with employees, the self-employed in Europe were not only more satisfied with their jobs but they were also more satisfied with their pay (column 3), the type of work they do (column 5), and the time they spend traveling to work. They were less satisfied with their hours of work - which are well known to be longer than those of employees. ${ }^{16}$ There was no difference between employees and the self-employed in their views on job security. This contrasts with the findings of Manski and Straub (2000) for the US who found that self-employed workers in the US see themselves as facing less job insecurity than do those who work for others. ${ }^{17}$ Consistent with Manski and Straub's findings, in Blanchflower and Oswald (1999) using data from the 1972-1996 General Social Surveys we found that the self-employed were less likely than employees to think that they would lose their job in the next 12 months and more likely to say it would be easy for them to find a job with another employer with approximately the same income and fringe benefits they currently had. ${ }^{18}$ Similar results were found when I extended the analysis to 2002 using the most recent dataset available. ${ }^{19}$

The finding that the self-employed report higher levels of job satisfaction than employees is a rather robust finding across the nations on which data are available. This result has been known

16 Average hours for the self-employed and employees are available on a consistent basis in the 1999 ISSP, $\mathrm{N}=15,729$. Only in Russia and Chile do the self-employed work less hours than employees.

\begin{tabular}{|l|c|c|l|c|c|}
\hline & Employees & Self-employed & & Employees & Self-Employed \\
\hline Australia & 36.4 & 39.4 & Latvia & 42.0 & 44.2 \\
\hline Bulgaria & 42.1 & 54.6 & New Zealand & 40.0 & 46.3 \\
\hline Canada & 39.1 & 41.4 & Northern Ireland & 34.4 & 43.7 \\
\hline Chile & 48.2 & 46.5 & Norway & 39.0 & 45.7 \\
\hline Cyprus & 38.4 & 42.6 & Poland & 42.9 & 56.5 \\
\hline Czech Republic & 43.7 & 52.0 & Portugal & 41.5 & 47.0 \\
\hline East Germany & 41.3 & 56.7 & Russia & 39.0 & 36.5 \\
\hline France & 37.1 & 49.9 & Slovakia & 43.5 & 56.3 \\
\hline Great Britain & 38.6 & 42.6 & Slovenia & 43.0 & 52.0 \\
\hline Hungary & 46.1 & 51.8 & Spain & 45.2 & 49.9 \\
\hline Israel & 38.5 & 42.8 & Sweden & 38.5 & 47.2 \\
\hline Japan & 47.3 & 51.6 & United States & 40.3 & 44.7 \\
\hline West Germany & 39.7 & 54.2 & & & \\
\hline
\end{tabular}

17 For other work on job security in the United States, that also used the General Social Surveys but does not explicitly identify the self-employed, see Schmidt (1999).

${ }^{18}$ The exact wording of the questions in the GSS was as follows Q180A - "Thinking about the next 12 months, how likely do you think it is that you will lose your job or be laid off -- very likely, fairly likely, not too likely, or not at all likely?" Q180B “About how easy would it be for you to find a job with another employer with approximately the same income and fringe benefits you now have? Would you say very easy, somewhat easy, or not easy at all?"

19 For both variables ordered logit equations were estimated for the years 1972-2002 using the GSS. In the former case relating to the probability of losing a job, the controls were time, male, age $(-)$, black $(+)$, Other races $(+)$, years of education (-) where $(-)=$ significant and negative $(+)=$ significant and positive. Sample size was 13,532 . The selfemployment dummy had a coefficient of -.7446 and a t-statistic of 12.08. In the second equation modeling the probability of finding a job the same list of controls were included: time(+) male(-) age(-) black(-) other race, years of education $(+)$. Sample size $=13,444$. The self-employment dummy in the job finding equation had a coefficient of +.5055 and a t-statistic of 10.08 . 
for a long time in the psychology literature, see, for example, Eden (1975), Katz (1993) and Weaver and Franz (1992) but is less known in economics. Recent example in economics are Blanchflower and Oswald (1998, 1999), Blanchflower (2000), Frey and Benz (2002, 2003), Hundley (2001). In an important paper Frey and Benz (2002) examine job satisfaction data for the UK, Germany and Switzerland and also find evidence that the self-employed are more satisfied at work than employees. What is impressive about this paper is that the authors have panel data over a number of years on the same individuals for both the UK (1991-1999) and Germany (1984-2000) and show that this result remains even in the presence of people specific fixed effects (Table 2). Frey and Benz also provide evidence from a 'natural experiment' in East Germany: people who moved into self-employment after the fall of the Berlin Wall in 1989 saw a large and highly significant jump in their levels of job satisfaction compared to those experienced by East Germans who worked as employees before and after 1989. These 'fixed effects' and 'natural experiment' results are especially convincing that there is something real going on and the results are not simply being driven by selection. The paper is important as it makes clear make clear that the direction of causality is clear - self-employment makes people happy, it is not the reverse direction of causality that it is happy people who decide to become self-employed.

Benz and Frey (2003) examined data on 23 countries from the International Social Survey Programme (ISSP) conducted in 1997 and also used by Blanchflower, Oswald and Stutzer (2001). Benz and Frey conclude that the self-employed are more satisfied with their jobs because they enjoy 'greater autonomy and independence'. In a recent paper Hundley (2001) provides results for the USA which are similar to those of Frey and Benz. His main findings are that the self-employed are more satisfied because their work provides more autonomy, flexibility and skill utilization and greater job security. However, our evidence is not consistent with his finding for the US that the self-employed are more secure in their jobs than the employed. He concluded that "a sizable portion of the difference in job satisfaction between the self- and organizationally employed is attributable to factors related to the independence of the selfemployed from the routines and constraints of organizational life", (p311, 2001). As we will show below, this greater autonomy and flexibility comes at a cost: self-employment is very stressful on both the individual and his family: the self-employed come home tired and exhausted from their labors.

For the first time I am aware of it is possible to distinguish between the satisfaction levels of the most successful self-employed who have one or more employees and self-employed without any employed $^{20}$. Both groups are unique in that they have created jobs for themselves but the former group are especially interesting as they have created jobs for others - they are the job makers in our economies. The process by which jobs are created and by which firms are born is little understood and an obvious area for study. Both of these groups of self-employed are more satisfied with their jobs than are employees: the effect is greater for those with employees than for those without. Data are available from a Eurobarometer Survey \#44.3OVR, February-April

\footnotetext{
${ }^{20}$ Surprisingly there is little if any published literature on job makers. One exception is Fölster (2000) who looks at the link between self-employment and employment using Swedish panel data on counties. He finds support for the notion that increased self-employment has a positive effect on employment.
} 
1996 - ICPSR\#2443 that allow us to identify employees as well as the self-employed with and without employees.

\begin{tabular}{|l|c|c|c|}
\hline & $\begin{array}{c}\text { Self-employed } \\
\text { with employees }\end{array}$ & $\begin{array}{c}\text { Self-employed } \\
\text { no employees }\end{array}$ & Employees \\
\hline Austria & 5.38 & 5.20 & 5.34 \\
\hline Belgium & 5.53 & 5.21 & 5.18 \\
\hline Denmark & 6.10 & 6.14 & 5.51 \\
\hline East Germany & 5.60 & 5.28 & 5.14 \\
\hline Eire & 5.11 & 5.27 & 4.79 \\
\hline Finland & 6.24 & 5.71 & 5.25 \\
\hline France & 5.40 & 4.94 & 4.77 \\
\hline Great Britain & 5.56 & 5.25 & 4.94 \\
\hline Greece & 4.58 & 4.46 & 4.87 \\
\hline Italy & 5.54 & 5.06 & 4.71 \\
\hline Luxembourg & 5.24 & 5.80 & 5.17 \\
\hline Netherlands & 6.17 & 6.14 & 5.51 \\
\hline Northern Ireland & 5.60 & 5.25 & 4.94 \\
\hline Portugal & 4.85 & 4.81 & 4.82 \\
\hline Spain & 5.76 & 5.25 & 4.92 \\
\hline Sweden & 5.39 & 5.74 & 5.24 \\
\hline West Germany & 6.06 & 6.10 & 5.18 \\
\hline EU Weighted Average & 5.55 & 5.20 & 5.02 \\
\hline
\end{tabular}

On average in the EU the self-employed with employees report higher levels of job satisfaction than do the self-employed without employees; both groups have higher levels of satisfaction than employees. Exceptions to this general rule are found in Greece and Luxembourg where employees are the most satisfied and in Germany and Sweden where the self-employed with no employees have the highest satisfaction.

Table 8 presents evidence on twenty different aspects of an individual's work environment. Details of the questions asked are reported in Appendix 1. Each of the equations include controls for years of schooling, union membership, years of tenure, age, gender and private sector as well as controls for the two types of self-employment. The findings from these equations are as follows

4.1. In comparison with employees the self-employed with employees are especially likely to report that they are satisfied with their job, their pay, using their abilities, being able to take initiative, the variety of work.

4.2. In comparison with employees the self-employed with employees are especially likely to report that they are less satisfied with the hours they have to work.

4.3. In comparison with employees the self-employed with employees are especially likely to report that they find their work stressful; they come home from work exhausted; that their job limits their family time; that they felt too tired after work to enjoy the things they would like to 
do in the home; that their partner/family gets fed up with the pressure of their job; that they had lost sleep over worry; felt unhappy and depressed; were constantly under strain and worked under a great deal of pressure.

In a related study using data for Canada from the 1994 and 2002 Canadian General Social Surveys Williams (2003) found that self-employed individuals were significantly less likely than employees to report poor interpersonal relationships (10\% versus $16 \%)$, or fear of job loss $(8 \%$ versus $14 \%$ ) as a source of workplace stress ${ }^{21}$. However, they were slightly more likely than employees to feel stress as a result of too many hours or too many demands in their work environment (37\% versus 34\%). Williams reported that both the self-employed and full-time workers were significantly more likely to feel the time crunch of too many demands or hours at work, compared with their employee and part-time counterparts.

4.4. The effects for the self-employed without employees were generally smaller than for the self-employed with employees but still significantly different from employees.

4.5. The self-employed without employees were less satisfied than employees with their pay, the amount of work they have and their job security.

4.6. In comparison with the self-employed with employees those without employees were less likely to report finding their work stressful, coming home from work exhausted; that they felt too tired after work to enjoy the things they would like to do in the home; unhappy and depressed or that they worked under a great deal of pressure.

\subsection{The self-employed don't think of themselves as worthless people. They are go-getters!}

4.8. Table 9 reports further evidence on the attitudes of the self-employed across countries. The exact questions asked are reported in Appendix 2. Here I make use of data from the World Values Surveys (WVS), 1981-1984, 1990-1993, and 1995-1997 as well as from the Eurobarometer Survey Trend files (EBST), for 1975-1998 and estimate a series of ordered logits. In column 1 of the Table using data from one sweep of the WVS for 1995 for 45 countries it is apparent that the self-employed are much more likely to say that they place more weight on work than they do on leisure - they are motivated individuals. In column 2 of the table, which uses data on 64 countries and uses all three sweeps of the WVS, the self-employed report that they are more likely than employees to they have control over their lives. A similar answer is obtained in column 3 when the sample is expanded to include the retired, students, the unemployed, housewives and others, including those on military service. The coefficient on the selfemployment dummy remains significantly positive. Groups out of the labor force report that they are less in control of their lives than the employed. Finally, the last two columns report the results of estimating life satisfaction equations across 17 European countries. Column 4 contains 235,000 observations and is restricted to workers while column 5 includes the whole population and has approximately 480,000 observations. The self-employed are especially satisfied with the lives - significantly more so than employees and the retired, roughly equivalent to the

${ }^{21}$ In Canada according to the Labour Force Survey, between 1990 and 1997, self-employment accounted for over $75 \%$ of total job growth. 
satisfaction levels of housewives and student, and much more satisfied with their lives than are the unemployed ${ }^{22}$. When these equations are estimated separately by country with the same controls (results not reported) the self-employment variable is significantly positive in ten countries: Belgium, Denmark, East Germany, Greece, Ireland, Italy, Netherlands, Northern Ireland, Portugal, and West Germany. It should be noted, however, that the coefficient on the self-employment variable was insignificantly different from zero in eight countries: Austria, Finland, France, Great Britain, Luxembourg, Norway, Spain and Sweden. ${ }^{23}$ Even though the self-employed find their work environment full of stresses and strains they appear to be satisfied in their lives, prefer work over leisure and feel they have free choice and control over their lives. This is impressive evidence across many countries that the self-employed are different.

\section{Conclusions}

Self-employment rates are generally down across the OECD. The main exceptions are the UK, and New Zealand. There are strong patterns in the data across countries. The probability of being self-employed across the OECD is higher for men and for older workers compared with younger workers. In Europe the probabilities are lower the more educated an individual is, while the opposite is true in the US. Some groups of immigrants have higher rates of self-employment than the indigenous population, others do not. Capital constraints appear to bind especially tightly in the US for firms owned by minorities and women: the low rates of self-employment of blacks and Hispanics in the US appears in part to be driven by liquidity constraints. There is evidence that liquidity constraints bite in other countries including the UK, Finland, Australia, Canada and Sweden.

It does seem likely that people have an unrealistically rosy view of what it is like to be running their own business rather than staying with the comparative security of being an employee. A surprisingly high proportion of employees say they would prefer to be self-employed. Despite the fact that very high proportions of employees say they would like to set up their own business the reality is something else. The evidence presented her suggests that people may well be able to judge what is in their own best interests - that is why they remain as employees. The selfemployed work under a lot of pressure, report that they find their work stressful, that they come home from work exhausted they are constantly under strain and lose sleep over worry they place more weight on work than they do on leisure, they are especially likely to say they have control over their lives and report that they are highly satisfied with the lives. Being self-employed is tough work and appears to require rare talents. Self-employment isn't for everyone. More doesn't seem to be better.

22 For more on life satisfaction and happiness see Blanchflower (2001), Blanchflower and Oswald (2004) and Di Tella, MacCulloch and Oswald (2001, 2003).

23 In private communication Matthias Benz reported finding no significant effect for the self-employed in a life satisfaction equation for Switzerland. 
Table 1a. Self-employment as a \% of total employment (employees + self-employed)

\begin{tabular}{|c|c|c|c|c|c|c|}
\hline & 1956 & 1966 & 1976 & 1986 & 1996 & 2002 \\
\hline Australia & & 14.7 & 14.7 & 16.0 & 14.1 & 13.8 \\
\hline Austria & & $28.8^{\mathrm{a}}$ & 19.2 & 10.6 & 11.0 & $11.0^{b}$ \\
\hline Belgium & 20.0 & 17.9 & 13.7 & 14.9 & 15.7 & $15.1^{\mathrm{c}}$ \\
\hline Canada & 19.8 & 13.0 & 8.5 & 9.0 & 10.7 & 9.6 \\
\hline $\begin{array}{l}\text { Czech } \\
\text { Republic }\end{array}$ & & & & & 11.9 & 15.6 \\
\hline Denmark & $23.6^{\mathrm{d}}$ & $23.5 \mathrm{f}$ & 13.8 & 9.6 & 8.6 & 8.3 \\
\hline Finland & $36.7^{\mathrm{g}}$ & 29.6 & 20.2 & 13.7 & 14.5 & 12.4 \\
\hline France & 34.0 & 25.2 & 17.8 & 14.7 & 10.3 & 8.7 \\
\hline Germany & $14.7^{\mathrm{e}}$ & 12.1 & 13.6 & 11.8 & 9.8 & 10. \\
\hline Greece & $51.1^{\mathrm{h}}$ & & $52.4^{\mathrm{i}}$ & 41.8 & 38.3 & 34.7 \\
\hline Hungary & & & & & 17.2 & 13.4 \\
\hline Iceland & & 18.3 & 15.2 & 13.5 & 17.8 & 16.4 \\
\hline Ireland & $30.9^{j}$ & 28.2 & 25.4 & 21.6 & 20.0 & 17.0 \\
\hline Italy & $44.5^{\mathrm{k}}$ & 37.2 & 29.2 & 25.9 & 26.1 & 24.6 \\
\hline Japan & 35.0 & 23.9 & 20.1 & 17.2 & 12.6 & 11.2 \\
\hline Korea & & 52.0 & 45.3 & 36.6 & 30.2 & 30.4 \\
\hline Luxembourg & $28.7^{\mathrm{d}}$ & 22.4 & 15.4 & 11.3 & 7.5 & 5.9 \\
\hline Mexico & & $23.2^{h}$ & $32.7^{1}$ & $27.4^{\mathrm{m}}$ & 33.3 & 31.8 \\
\hline Netherlands & 24.2 & & 12.7 & 11.3 & 11.4 & 11.1 \\
\hline $\begin{array}{l}\text { New } \\
\text { Zealand }\end{array}$ & 19.0 & 14.2 & 14.0 & 17.4 & 20.0 & 18.7 \\
\hline Norway & 23.3 & 20.3 & 11.2 & 9.7 & 7.9 & 6.8 \\
\hline Poland & $41.0^{\mathrm{d}}$ & 35.0 & 24.2 & 26.0 & 24.9 & 24.0 \\
\hline Portugal & 26.9 & 25.9 & 22.1 & 31.3 & 27.4 & 25.3 \\
\hline $\begin{array}{l}\text { Slovak } \\
\text { Republic }\end{array}$ & & & & & 6.3 & 8.5 \\
\hline Spain & & 28.0 & 23.8 & 23.8 & 22.0 & 17.8 \\
\hline Sweden & & 10.8 & 7.1 & 6.3 & 10.6 & 9.5 \\
\hline Switzerland & & & & & 10.7 & 9.7 \\
\hline Turkey & $24.7^{\mathrm{d}}$ & & & $42.1^{n}$ & 40.3 & $37.8^{b}$ \\
\hline UK & 7.7 & 6.7 & 8.0 & 11.7 & 12.8 & 11.5 \\
\hline USA & 15.2 & 11.3 & 8.4 & 8.5 & 8.3 & 7.2 \\
\hline
\end{tabular}

Notes $a=1968 ; b=2001 ; c=1999 ; d=1960 ; e=1957 ; f=1965 ; g=1959 ; h=1970 ; i=1977$; $\mathrm{j}=1961 ; \mathrm{k}=1958 ; \mathrm{l}=1980 ; \mathrm{m}=1990 ; \mathrm{n}=1988 ; \mathrm{o}=1967 \mathrm{p}=1955$.

Source: OECD Labour Force Statistics. ;

(http://www1.oecd.org/scripts/cde/members/LFSDATAAuthenticate.asp) 
Table $1 \mathrm{~b}$. Self-employment as a $\%$ of all non agricultural employment.

\begin{tabular}{|c|c|c|c|c|c|c|}
\hline & 1956 & 1966 & 1976 & 1986 & 1996 & 2002 \\
\hline Australia & & 10.2 & 11.1 & 12.8 & 11.9 & 12.1 \\
\hline Austria & & $13.6^{\mathrm{a}}$ & 9.5 & 6.3 & 7.0 & $7.8^{b}$ \\
\hline Belgium & 13.0 & 14.4 & 11.4 & 13.1 & 14.5 & $14.1^{\mathrm{c}}$ \\
\hline Canada & 9.6 & 7.7 & 6.1 & 7.2 & 9.2 & 8.7 \\
\hline $\begin{array}{l}\text { Czech } \\
\text { Republic }\end{array}$ & & & & & 11.8 & 15.6 \\
\hline Denmark & $15.5^{\mathrm{d}}$ & $14.3^{f}$ & 9.6 & 7.1 & 7.2 & 7.2 \\
\hline Finland & $11.2^{\mathrm{d}}$ & & 8.0 & 6.8 & 10.3 & 9.3 \\
\hline France & 19.5 & 14.2 & 10.9 & 9.8 & 7.7 & 6.7 \\
\hline Germany & $10.1^{\mathrm{e}}$ & 8.7 & 8.8 & 8.7 & 9.0 & 9.5 \\
\hline Greece & $30.9^{\mathrm{d}}$ & & $30.9^{i}$ & 29.0 & 29.1 & 26.4 \\
\hline Hungary & & & & & 16.6 & 11.8 \\
\hline Iceland & & 9.9 & 8.5 & 9.5 & 15.0 & 13.8 \\
\hline Ireland & & 9.8 & 10.6 & 11.1 & 12.9 & 12.7 \\
\hline Italy & $27.6^{\mathrm{k}}$ & 26.1 & 22.5 & 22.6 & 24.3 & 23.2 \\
\hline Japan & 22.8 & 15.6 & 14.7 & 13.6 & 10.1 & 9.1 \\
\hline Korea & & & & 27.1 & 25.1 & 26.0 \\
\hline Luxembourg & $16.1^{\mathrm{d}}$ & 13.4 & 9.9 & 8.2 & 6.4 & 5.1 \\
\hline Mexico & & $19.0^{\mathrm{h}}$ & $21.6^{1}$ & $20.7^{\mathrm{m}}$ & 27.4 & 27.2 \\
\hline Netherlands & 16.6 & $14.7^{j}$ & 8.9 & 8.2 & 9.9 & 9.9 \\
\hline $\begin{array}{l}\text { New } \\
\text { Zealand }\end{array}$ & $9.3^{j}$ & 8.3 & 9.5 & 13.5 & 16.6 & 15.8 \\
\hline Norway & 10.9 & 9.5 & 7.1 & 6.6 & 5.5 & 4.9 \\
\hline Poland & $3.2^{\mathrm{d}}$ & 2.7 & 2.0 & 5.1 & 11.5 & 12.1 \\
\hline Portugal & 16.7 & 15.0 & 11.8 & 16.9 & 19.9 & 17.7 \\
\hline $\begin{array}{l}\text { Slovak } \\
\text { Republic }\end{array}$ & & & & & 6.6 & 8.6 \\
\hline Spain & & & & 16.0 & 18.4 & 15.7 \\
\hline Sweden & & $6.9^{\circ}$ & 4.4 & 4.2 & 9.1 & 8.5 \\
\hline Turkey & $33.9^{p}$ & & & & 25.8 & $24.0 \mathrm{~b}$ \\
\hline UK & 6.4 & 5.6 & 7.0 & 10.8 & 12.0 & 11.0 \\
\hline USA & 10.3 & 8.7 & 6.8 & 7.4 & 7.3 & 6.4 \\
\hline \multicolumn{7}{|c|}{$\begin{array}{l}\text { Notes } a=1968 ; b=2001 ; c=1999 ; d=1960 ; \mathrm{e}=1957 ; \mathrm{f}=1965 ; \mathrm{g}=1959 ; \mathrm{h}=1970 ; \mathrm{i}=1977 ; \\
\mathrm{j}=1961 ; \mathrm{k}=1958 ; \mathrm{l}=1980 ; \mathrm{m}=1990 ; \mathrm{n}=1988 \text {. }\end{array}$} \\
\hline
\end{tabular}


Table 2. Trends in self-employment by country, 1955-2002.

\begin{tabular}{|c|c|c|c|}
\hline & All & $\begin{array}{l}\text { Non- } \\
\text { agricultural }\end{array}$ & Agricultural \\
\hline Australia (1964-2002) & 0 & + & - \\
\hline Austria (1968-2001) & - & - & - \\
\hline Belgium (1956-1999) & - & 0 & - \\
\hline Canada (1956-2002) & - & 0 & - \\
\hline Switzerland (1991-2002) & - & $\mathrm{n} / \mathrm{a}$ & $\mathrm{n} / \mathrm{a}$ \\
\hline Czech Republic (1993-2002) & + & + & + \\
\hline Germany $(1957-2002)$ & - & - & - \\
\hline Denmark $(1960,1965,1967,1969-2002)$ & - & - & - \\
\hline Finland (1959-2002) & - & + & - \\
\hline France (1956-2002) & - & - & - \\
\hline Greece (1960-1, 1977-2002) & - & - & + \\
\hline Hungary (1992-2002) & - & - & + \\
\hline Eire $(1961,1965-2002)$ & - & + & - \\
\hline Iceland (1964-2002) & 0 & + & - \\
\hline Italy (1958-2002) & - & - & - \\
\hline Japan (1956-2002) & - & - & - \\
\hline Korea $(1963-2002)$ & - & - & + \\
\hline Luxembourg (1960-2002) & - & - & 0 \\
\hline Mexico $(1970,1980,1990-2002)$ & 0 & + & 0 \\
\hline Netherlands (1956-2002) & - & - & - \\
\hline Norway (1956-2002) & - & - & - \\
\hline $\begin{array}{l}\text { New Zealand }(1956,1961,1966,1971,1976 \text {, } \\
\text { 1979-2002) }\end{array}$ & + & + & 0 \\
\hline Poland (1960-2002) & - & + & 0 \\
\hline Portugal (1956-2002) & 0 & + & + \\
\hline Slovak Republic (1994-2002) & + & + & + \\
\hline Spain $(1960-2002)$ & - & + & - \\
\hline Sweden (1963-2002) & 0 & + & 0 \\
\hline Turkey $(1955,1960,1961,1988-2002)$ & 0 & - & 0 \\
\hline UK (1956-2002) & + & + & + \\
\hline USA (1955-2002) & - & - & - \\
\hline \multicolumn{4}{|c|}{$\begin{array}{l}\text { Notes: regressions include only a time trend. } 0=\text { not significant, }+=\text { positive and significant }-= \\
\text { negative and significant all on a two-tailed test at the } 95 \% \text { significance level. }\end{array}$} \\
\hline \multicolumn{4}{|c|}{$\begin{array}{l}\text { Source: OECD Labour Force Statistics. ; } \\
\text { (http://www1.oecd.org/scripts/cde/members/LFSDATAAuthenticate.asp) }\end{array}$} \\
\hline
\end{tabular}




\begin{tabular}{|c|c|c|c|c|c|c|}
\hline & \multicolumn{2}{|c|}{ All } & \multicolumn{2}{|c|}{ Non-agricultural sector } & \multicolumn{2}{|c|}{ Agricultural sector } \\
\hline & $(1)$ & $(2)$ & (3) & $(4)$ & $(5)$ & $(6)$ \\
\hline Time & $.0024(26.91)$ & $-.0001(2.32)$ & $-.0002(2.61)$ & $.0001(2.01)$ & $-.0020(7.57)$ & $-.0009(4.72)$ \\
\hline Self Employment $t_{t-1}$ & & $.9088(86.74)$ & & $.8892(68.94)$ & & $.6349(26.97)$ \\
\hline Austria & $.0141(1.62)$ & $-.0036(1.35)$ & $-.0305(5.04)$ & $-.0054(2.27)$ & $.2224(9.42)$ & $.0805(4.52)$ \\
\hline Belgium & $-.0011(0.14)$ & $.0000(0.02)$ & $.0163(2.87)$ & $.0022(0.98)$ & $.1960(8.84)$ & $.0676(4.07)$ \\
\hline Canada & $-.0427(5.30)$ & $-.0050(1.99)$ & $-.0383(6.84)$ & $-.0044(1.96)$ & $-.0845(3.88)$ & $-.0365(2.31)$ \\
\hline Czech Republic & $.0152(1.15)$ & $.0068(1.64)$ & $.0132(1.44)$ & $.0067(1.80)$ & $-.4638(12.93)$ & $-.1559(5.41)$ \\
\hline Denmark & $-.0261(3.02)$ & $-.0052(1.90)$ & $-.0301(5.01)$ & $-.0055(2.27)$ & $-.0316(1.35)$ & $-.0155(0.90)$ \\
\hline Eire & $.0891(10.59)$ & $.0056(2.06)$ & $-.0006(0.11)$ & $.0004(0.21)$ & $.2098(9.21)$ & $.0786(4.56)$ \\
\hline Finland & $.0358(4.38)$ & $-.0013(0.53)$ & $-.0349(5.72)$ & $-.0036(1.49)$ & $.1311(5.51)$ & $.0464(2.64)$ \\
\hline France & $.0275(3.41)$ & $-.0017(0.69)$ & $-.0031(0.57)$ & $-.0029(1.35)$ & $.1293(5.93)$ & $.0455(2.85)$ \\
\hline Germany & $-.0379(4.69)$ & $-.0034(1.36)$ & $-.0281(5.00)$ & $-.0032(1.46)$ & $.0283(1.29)$ & $.0073(0.46)$ \\
\hline Greece & $.2846(30.89)$ & $.0185(4.45)$ & $.1771(27.66)$ & $.0179(5.23)$ & $.3156(12.65)$ & $.1216(6.25)$ \\
\hline Hungary & $.0471(3.70)$ & $-.0027(0.68)$ & $.0300(3.13)$ & $-.0039(0.99)$ & $-.2792(7.46)$ & $-.0744(2.59)$ \\
\hline Iceland & $.0121(1.44)$ & $.0015(0.59)$ & $-.0087(1.49)$ & $.0000(0.02)$ & $-.1190(5.22)$ & $-.0426(2.56)$ \\
\hline Italy & $.1430(17.58)$ & $.0095(3.28)$ & $.1194(21.12)$ & $.0121(4.52)$ & $-.0219(1.00)$ & $-.0124(0.78)$ \\
\hline Japan & $.0426(5.30)$ & $-.0000(0.02)$ & $.0269(4.82)$ & $.0001(0.08)$ & $.2057(9.43)$ & $.0736(4.48)$ \\
\hline Korea & $.2480(29.66)$ & $.0173(4.73)$ & $.1455(21.38)$ & $.0137(4.20)$ & $.2463(9.28)$ & $.0966(4.82)$ \\
\hline Luxembourg & $-.0083(1.02)$ & $-.0051(2.06)$ & $-.0209(3.68)$ & $-.0049(2.20)$ & $.9426(27.28)$ & $.4331(12.85)$ \\
\hline Mexico & $.2026(17.88)$ & $.0223(5.09)$ & $.1437(18.25)$ & $.0210(5.43)$ & $-.0002(0.01)$ & $.0193(0.81)$ \\
\hline Netherlands & $-.0141(1.63)$ & $-.0046(1.73)$ & $-.0149(2.46)$ & $-.0039(1.66)$ & $.0242(1.03)$ & $.0049(0.29)$ \\
\hline New Zealand & $.0434(4.56)$ & $.0033(1.02)$ & $.0194(2.94)$ & $.0057(2.02)$ & $-.0318(1.23)$ & $-.0208(1.04)$ \\
\hline Norway & $-.0227(2.80)$ & $-.0045(1.82)$ & $-.0422(7.51)$ & $-.0059(2.61)$ & $.0723(3.30)$ & $.0245(1.55)$ \\
\hline Poland & $.1304(15.86)$ & $.0087(3.04)$ & $-.0584(10.23)$ & $-.0046(1.95)$ & $.1881(8.45)$ & $.0689(4.16)$ \\
\hline Portugal & $.1075(13.34)$ & $.0105(3.89)$ & $.0417(7.46)$ & $.0048(2.13)$ & $.0093(0.43)$ & $.0116(0.74)$ \\
\hline Slovak Republic & $-.0395(2.86)$ & $-.0022(0.51)$ & $-.0402(4.19)$ & $-.0033(0.85)$ & $-.5483(14.65)$ & $-.1920(6.23)$ \\
\hline Spain & $.0975(11.86)$ & $.0048(1.79)$ & $.0420(7.36)$ & $.0027(1.19)$ & $-.0208(0.93)$ & $-.0079(0.50)$ \\
\hline Sweden & $-.0580(6.94)$ & $-.0055(2.12)$ & $-.0511(8.57)$ & $-.0056(2.32)$ & $-.0348(1.50)$ & $-.0099(0.59)$ \\
\hline
\end{tabular}




\begin{tabular}{|l|c|c|c|c|c|c|}
\hline Switzerland & $-.0114(0.93)$ & $-.0011(0.31)$ & $\mathrm{n} / \mathrm{a}$ & $\mathrm{n} / \mathrm{a}$ & $\mathrm{n} / \mathrm{a}$ & $\mathrm{n} / \mathrm{a}$ \\
\hline Turkey & $.2754(25.47)$ & $.0229(4.77)$ & $.1540(19.58)$ & $.0133(3.54)$ & $.2728(8.90)$ & $.1093(4.56)$ \\
\hline $\mathrm{UK}$ & $-.0613(7.61)$ & $-.0037(1.45)$ & $-.0302(5.40)$ & $-.0023(1.06)$ & $-.1922(8.81)$ & $-.0669(4.09)$ \\
\hline USA & $-.0605(7.54)$ & $-.0061(2.43)$ & $-.0369(6.63)$ & $-.0059(2.68)$ & $-.1107(5.07)$ & $-.0458(2.88)$ \\
\hline Constant & $.2176(33.53)$ & $.0156(5.06)$ & $.1211(26.71)$ & $.0115(4.84)$ & $.6821(38.44)$ & $.2553(12.31)$ \\
\hline & & & & & & \\
\hline $\mathrm{N}$ & & & 1064 & & 1017 & .7633 \\
\hline Adjusted R \\
\hline $\mathrm{F}$ & .8643 & .9867 & .8376 & .9750 & .8800 \\
\hline
\end{tabular}


Table 4a. Probability of Being Self-Employed - Europe (Probit Equation)

\begin{tabular}{|c|c|c|}
\hline & $(1)$ & $(2)$ \\
\hline Time trend & $-.0004(5.65)$ & $.0000(0.03)$ \\
\hline Austria & $.0264(4.09)$ & $.0209(2.75)$ \\
\hline Belgium & $.0884(23.94)$ & $.0825(21.38)$ \\
\hline Denmark & $-.0302(6.87)$ & $-.0247(5.35)$ \\
\hline East Germany & $-.0104(2.95)$ & $-.0115(3.02)$ \\
\hline Eire & $.0184(2.82)$ & $.0131(1.96)$ \\
\hline Finland & $.0048(0.57)$ & $.0116(1.11)$ \\
\hline Great Britain & $.0009(0.49)$ & $-.0092(4.70)$ \\
\hline Greece & $.2270(49.17)$ & $.2093(42.68)$ \\
\hline Italy & $.1544(70.88)$ & $.1394(60.84)$ \\
\hline Luxembourg & $.0115(0.71)$ & $.0160(0.93)$ \\
\hline Netherlands & $-.0230(7.41)$ & $-.0163(4.93)$ \\
\hline Northern Ireland & $-.0195(2.20)$ & $-.0244(2.69)$ \\
\hline Portugal & $.0997(22.69)$ & $.0817(17.47)$ \\
\hline Spain & $.1403(49.23)$ & $.1274(41.71)$ \\
\hline Sweden & $.0060(1.00)$ & $.0053(0.72)$ \\
\hline West Germany & $.0003(0.20)$ & $-.0042(2.26)$ \\
\hline Age & & $.0063(25.27)$ \\
\hline $\mathrm{Age}^{2}$ & & $-.00004(14.19)$ \\
\hline Male & & $.0244(21.83)$ \\
\hline Age left school 15 & & $-.0144(7.50)$ \\
\hline Age left school 16 & & $-.0117(6.23)$ \\
\hline Age left school 17 & & $-.0139(6.54)$ \\
\hline Age left school 18 & & $-.0149(7.92)$ \\
\hline Age left school 19 & & $-.0265(11.79)$ \\
\hline Age left school 20 & & $-.0233(9.23)$ \\
\hline Age left school 21 & & $-.0335(11.69)$ \\
\hline Age left school 22 or older & & $-.0666(40.83)$ \\
\hline Age left school still studying & & $-.0632(9.74)$ \\
\hline $\mathrm{N}$ & 383,559 & 333,456 \\
\hline $\mathrm{Chi}^{2}$ & 13028.05 & 19125.6 \\
\hline Log likelihood & -137875.1 & -116186.3 \\
\hline Pseudo $\mathrm{R}^{2}$ & .0451 & .0760 \\
\hline
\end{tabular}

Notes: The dependent variable is 1 if self-employed and zero if employed. T-statistics are in parentheses. Sample consists of non-agricultural workers only. Estimation procedure is dprobit in STATA. Sample weights are included so that the estimates are representative of the EU

Source: Eurobarometer Surveys, 1975-1999. Excluded category France and left school at age 14 or less. 


\begin{tabular}{|c|c|c|c|c|}
\hline & $(1)$ & $(2)$ & $(3)$ & (4) \\
\hline & $1979-1991$ & $1992-2002$ & 1994-2002 & $1994-2002$ \\
\hline & & & & US Born \\
\hline \multirow{2}{*}{ Female } & -.0466 & -.0271 & -.0259 & -.0235 \\
\hline & $(145.36)$ & $(66.35)$ & $(56.79)$ & $(47.40)$ \\
\hline \multirow[t]{2}{*}{ Black } & -.0459 & -.0440 & -.0431 & -.0433 \\
\hline & $(88.62)$ & $(65.57)$ & $(55.40)$ & $(52.68)$ \\
\hline \multirow[t]{2}{*}{ Hispanic } & -.0291 & -.0374 & -.0346 & -.0342 \\
\hline & $(45.37)$ & $(52.93)$ & $(32.35)$ & $(29.23)$ \\
\hline \multirow[t]{2}{*}{ Other races } & -.0102 & & & \\
\hline & $(12.07)$ & & & \\
\hline \multirow[t]{2}{*}{ Asian } & & -.0060 & -.0167 & -.0260 \\
\hline & & $(5.86)$ & $(9.27)$ & $(11.19)$ \\
\hline \multirow[t]{2}{*}{ American Indian } & & -.0213 & -.0229 & -.0228 \\
\hline & & $(11.70)$ & $(11.38)$ & $(10.83)$ \\
\hline \multirow[t]{2}{*}{ Age } & .0122 & .0108 & .0103 & .0104 \\
\hline & $(216.13)$ & $(138.37)$ & $(117.08)$ & $(110.74)$ \\
\hline \multirow[t]{2}{*}{$\mathrm{Age}^{2}$} & -.0001 & -.0001 & -.0001 & -.0001 \\
\hline & $(158.38)$ & $(92.49)$ & $(76.26)$ & $(71.81)$ \\
\hline \multirow{2}{*}{ Construction } & -.0526 & -.0481 & -.0526 & -.0523 \\
\hline & $(60.76)$ & $(44.62)$ & $(45.29)$ & $(40.44)$ \\
\hline \multirow[t]{2}{*}{ Repair services } & -.0188 & -.0204 & -.0281 & -.0271 \\
\hline & $(14.60)$ & $(13.50)$ & $(17.48)$ & $(15.20)$ \\
\hline \multirow[t]{2}{*}{ Personal services } & -.0209 & -.0490 & -.0524 & -.0507 \\
\hline & $(17.89)$ & $(43.66)$ & $(43.09)$ & $(36.89)$ \\
\hline \multirow[t]{2}{*}{ Years of education } & .0100 & No & No & No \\
\hline & $(171.52)$ & & & \\
\hline Schooling dummies & No & Yes & Yes & Yes \\
\hline Year dummies & Yes & Yes & Yes & Yes \\
\hline Country Dummies & No & No & Yes & No \\
\hline Industry Dummies & Yes & Yes & Yes & Yes \\
\hline State Dummies & Yes & Yes & Yes & Yes \\
\hline $\mathrm{N}$ & $2,810,390$ & $1,994,519$ & $1,580,392$ & $1,385,978$ \\
\hline Pseudo $\mathrm{R}^{2}$ & .2543 & .2210 & .2167 & .2276 \\
\hline Log Likelihood & $-819,619$ & $-609,176$ & -483632 & -424302 \\
\hline \multicolumn{5}{|c|}{$\begin{array}{l}\text { Notes: Probit analysis is performed using the dProbit command in STATA on a sample of } \\
\text { workers. The percentages reported here are the coefficients from the Probit analysis and indicate } \\
\text { the percentage point differences in self-employment rates between the indicated group and } \\
\text { Whites. T-statistics in parentheses. Excluded industry is agricultural services. }\end{array}$} \\
\hline \multicolumn{5}{|c|}{ Source: Blanchflower and Wainwright (2004). } \\
\hline
\end{tabular}


Table 5. Latent Entrepreneurship: An International League Table

Suppose you were working and could choose between different kinds of jobs. Which would you prefer: being an employee or being self-employed?

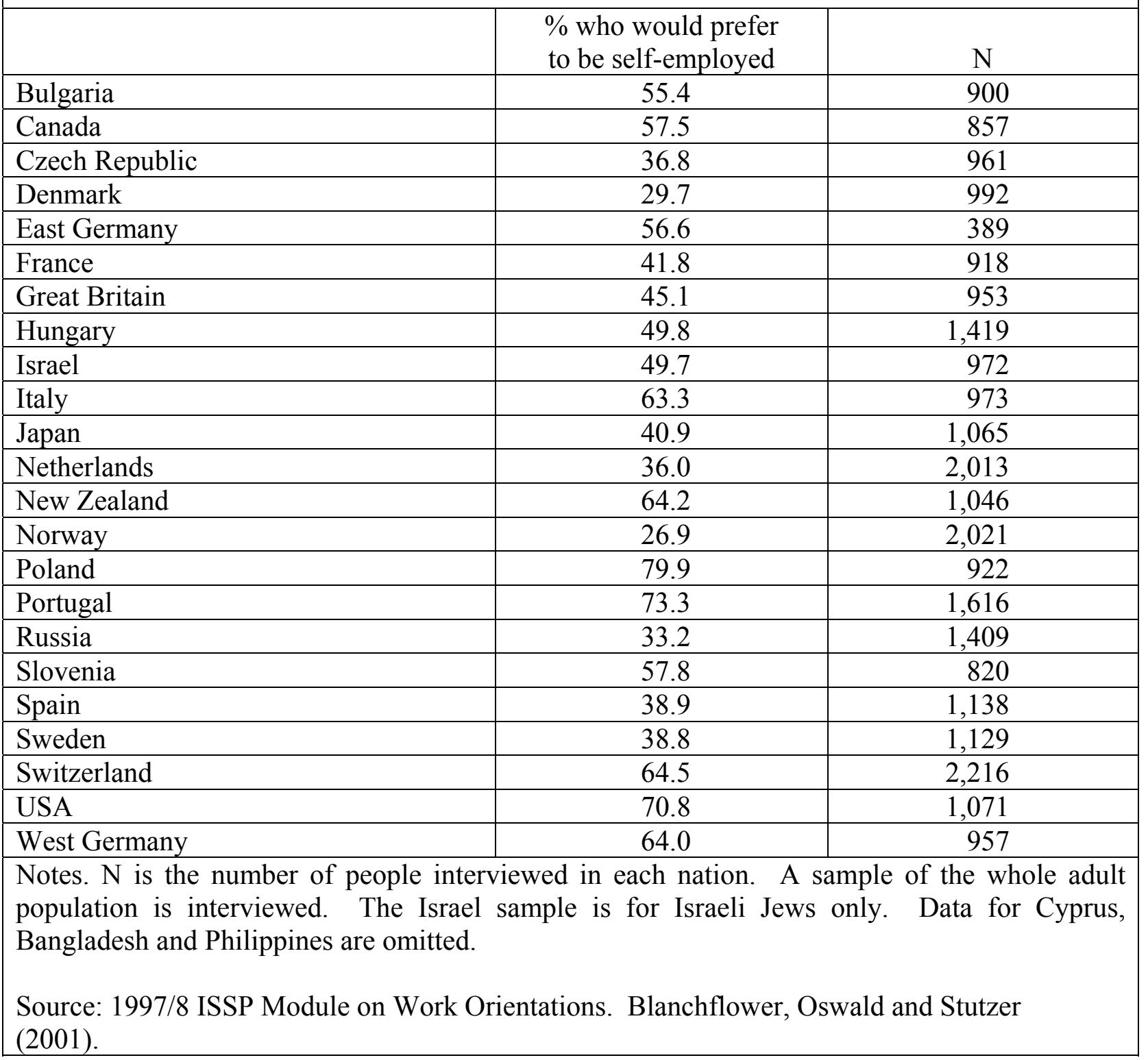


Table 6. Probability of Preferring to be Self-Employed (Probit Equation)

\begin{tabular}{|c|c|c|c|}
\hline & All & Male & Female \\
\hline Age & $-.0041(9.72)$ & $-.0043(7.62)$ & $-.0039(6.06)$ \\
\hline Male & $.1321(13.16)$ & $\mathrm{n} / \mathrm{a}$ & $\mathrm{n} / \mathrm{a}$ \\
\hline Part-time main job & $.0204(1.36)$ & $.0620(2.12)$ & $.0150(0.84)$ \\
\hline Less than part-time & $.0619(2.03)$ & $.1102(2.21)$ & $.0307(0.80)$ \\
\hline Years schooling & $.0023(1.52)$ & $.0038(1.93)$ & $-.0001(0.09)$ \\
\hline Bulgaria & $.0172(0.49)$ & $-.0456(0.95)$ & $.0903(1.73)$ \\
\hline Canada & $-.0379(1.08)$ & $-.1214(2.51)$ & $.0525(1.02)$ \\
\hline Czech Republic & $-.1826(5.50)$ & $-.2106(4.69)$ & $-.1446(2.95)$ \\
\hline Denmark & $-.3353(11.33)$ & $-.3640(8.74)$ & $-.2920(7.00)$ \\
\hline East Germany & $-.0252(0.56)$ & $-.0319(0.54)$ & $-.0123(0.18)$ \\
\hline France & $-.1697(5.46)$ & $-.1876(4.32)$ & $-.1349(3.03)$ \\
\hline Great Britain & $-.1536(4.58)$ & $-.1588(3.34)$ & $-.1303(2.76)$ \\
\hline Hungary & $-.0374(1.17)$ & $-.0814(1.90)$ & $.0202(0.43)$ \\
\hline Israel - Arabs & $-.0165(0.32)$ & $-.1020(1.67)$ & $.1639(1.67)$ \\
\hline Israel - Jews & $-.1015(2.82)$ & $-.1086(2.21)$ & $-.0861(1.64)$ \\
\hline Italy & $.0210(0.56)$ & $-.0314(0.67)$ & $.1002(1.64)$ \\
\hline Japan & $-.1683(5.00)$ & $-.2029(4.55)$ & $-.1221(2.40)$ \\
\hline New Zealand & $.0478(1.11)$ & $.0663(1.13)$ & $.0356(0.57)$ \\
\hline Norway & $-.3329(12.55)$ & $-.3330(9.13)$ & $-.3215(8.48)$ \\
\hline Poland & $.2363(6.20)$ & $.1637(3.13)$ & $.3148(5.63)$ \\
\hline Portugal & $.1936(6.11)$ & $.1324(3.12)$ & $-.2589(5.42)$ \\
\hline Russia & $-.2134(7.11)$ & $-.2668(6.59)$ & $-.1477(3.31)$ \\
\hline Slovenia & $.0120(0.34)$ & $-.0757(1.59)$ & $.1137(2.14)$ \\
\hline Sweden & $-.2035(6.61)$ & $-.2235(5.26)$ & $-.1691(3.81)$ \\
\hline Switzerland & $.0482(1.74)$ & $.0097(0.27)$ & $.0955(2.22)$ \\
\hline USA & $.1390(4.46)$ & $.1119(2.58)$ & $.1759(3.83)$ \\
\hline $\mathrm{N}$ & 11,988 & 6,359 & 5,629 \\
\hline $\mathrm{Chi}^{2}$ & 1673.8 & 676.2 & 858.5 \\
\hline Log likelihood & -7472.5 & -4023.49 & -3421.98 \\
\hline Pseudo $\mathrm{R}^{2}$ & 0.1007 & 0.0775 & 0.1115 \\
\hline \multicolumn{4}{|c|}{$\begin{array}{l}\text { Notes: Dummies were included but are not reported for Bangladesh, Philippines and Cyprus. } \\
\text { Excluded category West Germany. The dependent variable is } 1 \text { if wants to be self-employed anc } \\
\text { zero if would prefer to be an employee. T-statistics are in parentheses. Sample consists of } \\
\text { employees only. }\end{array}$} \\
\hline
\end{tabular}




\begin{tabular}{|c|c|c|c|c|c|c|c|}
\hline & $(1)$ & $(2)$ & (3) & (4) & (5) & (6) & $(7)$ \\
\hline & Job & Job & Pay & Security & Type of work & Hours & Travel time \\
\hline & USA & Europe & Europe & Europe & Europe & Europe & Europe \\
\hline Self-employed & $.5242(13.48)$ & $.3870(6.71)$ & $.1531(2.65)$ & $.0116(0.20)$ & $.4302(7.49)$ & $-.4024(6.95)$ & $.5973(10.19)$ \\
\hline Time & $-.0093(6.27)$ & & & & & & \\
\hline Years of schooling & .0404 (8.95) & $.0317(6.54)$ & $.0254(5.18)$ & $.0295(5.97)$ & $.0407(8.32)$ & $.0096(1.96)$ & $-.0071(1.43)$ \\
\hline Male & $-.0739(2.99)$ & $-.0043(0.12)$ & $.1517(3.74)$ & $-.0980(2.41)$ & $-.0637(1.57)$ & $-.2670(6.57)$ & $-.2880(6.98)$ \\
\hline Age & $.0123(2.12)$ & & $.0009(0.54)$ & $.0047(2.67)$ & $.0058(3.31)$ & $.0046(2.68)$ & $.0055(3.10)$ \\
\hline $\mathrm{Age}^{2}$ & $.0001(2.18)$ & & & & & & \\
\hline Black & $-.4218(11.37)$ & & & & & & \\
\hline Other races & $-.1858(2.77)$ & & & & & & \\
\hline Austria & & $.1584(1.44)$ & $.3027(2.71)$ & $.4573(4.10)$ & $.2194(1.99)$ & $.2236(2.04)$ & $.3528(3.17)$ \\
\hline Denmark & & $.2391(2.18)$ & $-.0362(0.33)$ & $.4773(4.31)$ & .4107 (3.69) & $.4199(3.79)$ & $.5045(4.44)$ \\
\hline East Germany & & $-.0830(0.71)$ & $-.4804(4.09)$ & $-.6298(5.41)$ & $.0199(0.17)$ & $-.4095(3.56)$ & $-.1682(1.45)$ \\
\hline Eire & & $-.0662(0.59)$ & $-.0306(0.27)$ & $.0481(0.43)$ & $.0224(0.20)$ & $-.0729(0.65)$ & $-.2801(2.43)$ \\
\hline Finland & & $-.2898(2.52)$ & $-.3516(2.98)$ & $.0300(0.25)$ & $-.4636(3.99)$ & $-.1076(0.92)$ & $.2214(1.85)$ \\
\hline France & & $-.4529(4.17)$ & $-.5291(4.88)$ & $-.3907(3.56)$ & $-.4760(4.36)$ & $-.6496(6.06)$ & $-.2395(2.21)$ \\
\hline Great Britain & & $-.4489(4.01)$ & $-.4070(3.62)$ & $-.2228(2.00)$ & $-.3244(2.90)$ & $-.1860(1.70)$ & $-.1827(1.64)$ \\
\hline Greece & & $-1.2687(10.45)$ & $-.9185(7.58)$ & $-1.0493(8.68)$ & $-1.0324(8.33)$ & $-.9228(7.64)$ & $-.9236(7.65)$ \\
\hline Italy & & $-.6997(6.26)$ & $-.5335(4.75)$ & $-.4249(3.80)$ & $-.6137(5.48)$ & $-.5530(5.02)$ & $-.4631(4.07)$ \\
\hline Luxembourg & & $-.0368(0.27)$ & $.0495(0.38)$ & $.2333(1.76)$ & $.0430(0.32)$ & $.1470(1.12)$ & $-.0983(0.73)$ \\
\hline Netherlands & & $-.3064(2.81)$ & $-.0184(0.17)$ & $.0405(0.37)$ & $-.2894(2.67)$ & $-.1483(1.38)$ & $-.2365(2.14)$ \\
\hline Northern Ireland & & $-.1424(0.81)$ & $-.4227(2.43)$ & $.0360(0.20)$ & $-.0129(0.07)$ & $-.0543(0.31)$ & $.1187(0.69)$ \\
\hline Portugal & & $-.9744(8.61)$ & $-.9355(8.23)$ & $-.6167(5.52)$ & $-.8398(7.40)$ & $-.9028(8.14)$ & $-.9311(8.27)$ \\
\hline Spain & & $-.5855(5.02)$ & $-.7314(6.28)$ & $-.4500(3.94)$ & $-.7079(6.15)$ & $-1.0451(9.11)$ & $-.8626(7.50)$ \\
\hline Sweden & & $\begin{array}{l}-.1574(1.43) \\
\end{array}$ & $-.9612(8.46)$ & $.0864(0.78)$ & $.0796(0.72)$ & $-.3597(3.23)$ & $.4571(3.98)$ \\
\hline West Germany & & $.1493(1.28)$ & $.1008(0.88)$ & $.3358(2.91)$ & $.1364(1.19)$ & $-.0255(0.22)$ & $-.0117(0.10)$ \\
\hline Cut 1 & -2.2303 & -3.4495 & -2.9144 & -2.8054 & -3.3185 & -3.8147 & -3.8531 \\
\hline Cut 2 & -.79220 & -2.9249 & -2.1991 & -2.302 & -2.6619 & -3.0992 & -3.2146 \\
\hline Cut_3 & 1.2277 & -2.2557 & -1.5899 & -1.6651 & -2.0702 & -2.4560 & -2.6894 \\
\hline Cut_4 & & -1.8197 & -1.0823 & -1.2292 & -1.6393 & -1.9545 & -2.2663 \\
\hline Cut 5 & & -1.0600 & -.3735 & -.5862 & -.9195 & -1.3152 & -1.6685 \\
\hline Cut 6 & & -.5312 & .1724 & -.1356 & -.3720 & -.8386 & -1.2374 \\
\hline Cut_7 & & .2633 & .8904 & .4545 & .3550 & -.1586 & -.7099 \\
\hline Cut 8 & & 1.3587 & 1.9210 & 1.3264 & 1.3831 & .7450 & .0042 \\
\hline
\end{tabular}




\begin{tabular}{|c|c|c|c|c|c|c|c|}
\hline Cut_9 & & 2.1477 & 2.7630 & 2.1028 & 2.2246 & 1.4824 & .7001 \\
\hline $\mathrm{N}$ & 24,676 & 7,779 & 7,765 & 7,730 & 7,779 & 7,773 & 7,748 \\
\hline Likelihood ratio & -25688.5 & 15373.8 & -16722.9 & -16100.7 & -15106.5 & -16167.9 & -15080.4 \\
\hline $\mathrm{LR} \mathrm{Chi}^{2}$ & 1239.51 & 492.6 & 433.7 & 518.6 & 563.3 & 578.0 & 560.2 \\
\hline Pseudo R ${ }^{2}$ & .0236 & .0158 & .0128 & .0159 & .0183 & .0176 & .0183 \\
\hline \multicolumn{8}{|c|}{$\begin{array}{l}\text { Notes: US equations also include } 8 \text { region dummies. } \\
\text { Europe equations excluded category Belgium. All equations include } 11 \text { industry dummies and } 8 \text { 'ever been unemployed?' dummies. * }=\text { dprobit } \\
\text { Workers were asked to use the same scale in response to each of the following questions. 1) And how satisfied are you with your current job or business in } \\
\text { terms of earnings? 2) And in terms of job security? 3) And in terms of the type of work you do? 4) And in terms of the number of hours you work? 5) And in } \\
\text { terms of the time it takes to travel to work? }\end{array}$} \\
\hline Source: General & veys, 197 & Eurobaro & 2, January & $2001-1$ & & & \\
\hline
\end{tabular}




\begin{tabular}{|c|c|c|c|c|c|}
\hline & $(1)$ & $(2)$ & (3) & $(4)$ & $(5)$ \\
\hline & Job & Pay & Abilities & Initiative & Hours \\
\hline Self with employees & $.5428(5.69)$ & $.3236(3.49)$ & $.7308(7.65)$ & $1.3520(13.85)$ & $-.2640(2.86)$ \\
\hline Self no employees & $.3679(4.88)$ & $-.1442(1.97)$ & $.4620(6.19)$ & $1.2140(15.71)$ & $-.1814(2.46)$ \\
\hline Years of schooling & $.0089(1.58)$ & $.0129(2.29)$ & $.0284(5.02)$ & $.0306(5.36)$ & $.0070(1.24)$ \\
\hline Private sector & $.1000(1.79)$ & $.1461(2.65)$ & $.0153(0.28)$ & $.0300(0.54)$ & $-.0317(0.57)$ \\
\hline Union member & $-.2177(4.07)$ & $-.1220(2.30)$ & $-.1505(2.83)$ & $-.1594(2.99)$ & $-.0215(0.41)$ \\
\hline Years of tenure & $.0037(1.19)$ & $.0039(1.28)$ & $.0097(3.15)$ & $.0012(0.41)$ & $.0008(0.27)$ \\
\hline Male & $-.1071(2.33)$ & $.0323(0.71)$ & $-.0170(0.37)$ & $.0056(0.12)$ & $-.2442(5.34)$ \\
\hline Age & $-.0326(2.67)$ & $-.0240(1.98)$ & $-.0005(0.05)$ & $.0221(1.81)$ & $-.0226(1.86)$ \\
\hline $\mathrm{Age}^{2}$ & $.0004(3.00)$ & $.0003(2.25)$ & $.0000(0.45)$ & $-.0001(1.13)$ & $.0003(2.53)$ \\
\hline Austria & $.3185(2.54)$ & $.4421(3.58)$ & $.3539(2.85)$ & $.0674(0.54)$ & $.2879(2.39)$ \\
\hline Denmark & $.7046(5.72)$ & $.2645(2.13)$ & $.8651(6.88)$ & $1.1399(9.06)$ & $.7306(5.89)$ \\
\hline East Germany & .1513 (1.19) & $.0065(0.05)$ & $.3766(2.98)$ & $.4405(3.47)$ & $-.0333(0.27)$ \\
\hline Eire & $-.2112(1.60)$ & $-.3585(2.81)$ & $-.1717(1.32)$ & $.0582(0.45)$ & $-.1713(1.35)$ \\
\hline Finland & $.4014(3.06)$ & $-.1646(1.26)$ & $.5480(4.17)$ & $.6106(4.63)$ & $.0672(0.51)$ \\
\hline France & $-.5574(4.77)$ & $-.6986(5.97)$ & $-.3166(2.69)$ & $-.1185(1.00)$ & $-.2579(2.23)$ \\
\hline Great Britain & $-.0749(0.61)$ & $-.2503(2.05)$ & $.0443(0.36)$ & $.5661(4.60)$ & $-.1480(1.23)$ \\
\hline Greece & $-.7448(5.83)$ & $-.4415(3.51)$ & $-.1926(1.51)$ & $.0107(0.08)$ & $-.6390(5.16)$ \\
\hline Italy & $-.5231(4.26)$ & $-.6523(5.36)$ & $-.2606(2.12)$ & $-.5152(4.19)$ & $-.1442(1.20)$ \\
\hline Luxembourg & $.0324(0.22)$ & $.3435(2.36)$ & $.1423(0.97)$ & $.0773(0.53)$ & $-.1109(0.79)$ \\
\hline Netherlands & $.6650(5.40)$ & $.5266(4.27)$ & $.5935(4.80)$ & $.8258(6.68)$ & $.8806(7.20)$ \\
\hline Northern Ireland & $-.3184(1.63)$ & $-.2494(1.28)$ & $.0005(0.00)$ & $.0896(0.46)$ & $-.1534(0.81)$ \\
\hline Portugal & $-.4713(3.72)$ & $-.7292(5.78)$ & $-.1860(1.48)$ & $-.3097(2.45)$ & $-.4901(3.99)$ \\
\hline Spain & $-.2139(1.65)$ & $-.2189(1.72)$ & $-.2226(1.73)$ & $-.2464(1.90)$ & $-.4804(3.84)$ \\
\hline Sweden & $.1384(1.16)$ & $-.5958(4.95)$ & $.6177(5.12)$ & $1.0271(8.45)$ & $.3266(2.73)$ \\
\hline West Germany & $.1344(1.08)$ & $.2097(1.68)$ & $.3622(2.87)$ & $.3132(2.49)$ & $-.0810(0.66)$ \\
\hline Cut_1 & -4.2220 & -2.4020 & -2.4527 & -1.5271 & -3.0383 \\
\hline
\end{tabular}




\begin{tabular}{|c|c|c|c|c|c|}
\hline & $(6)$ & $(7)$ & $(8)$ & $(9)$ & $(10)$ \\
\hline & Amount work & Variety & Job security & Stressful & Exhausted \\
\hline Self with employees & $.0468(0.51)$ & $.5313(5.77)$ & $.1089(1.17)$ & $.6500(6.82)$ & $.5497(5.83)$ \\
\hline Self no employees & $-.1513(2.03)$ & $.2598(3.53)$ & $-.4060(5.54)$ & $.0993(1.29)$ & $.1374(1.74)$ \\
\hline Years of schooling & $.0059(1.05)$ & $.0417(7.40)$ & $.0240(4.23)$ & $.0247(4.20)$ & $-.0005(0.09)$ \\
\hline Private sector & $.0032(0.06)$ & $.0046(0.08)$ & $-.0559(1.01)$ & $.0583(1.01)$ & $-.0078(0.14)$ \\
\hline Union member & $-.1431(2.71)$ & $-.1387(2.61)$ & $-.1016(1.90)$ & $.3001(5.38)$ & $.2975(5.38)$ \\
\hline Years of tenure & $.0012(0.40)$ & $-.0001(0.02)$ & $.0191(6.19)$ & $.0156(4.87)$ & $.0032(1.02)$ \\
\hline Male & $-.0687(1.52)$ & $-.0192(0.42)$ & $-.1007(2.21)$ & $-.0685(1.44)$ & $-.2582(5.42)$ \\
\hline Age & $-.0445(3.67)$ & $-.0079(0.66)$ & $-.0147(1.22)$ & $.0837(6.64)$ & $.0458(3.64)$ \\
\hline $\mathrm{Age}^{2}$ & $.0006(4.20)$ & $.0001(1.19)$ & $.0001(1.05)$ & $-.0011(7.27)$ & $-.0006(4.28)$ \\
\hline Austria & $.0863(0.71)$ & $.4350(3.55)$ & $.3288(2.68)$ & $.5769(4.45)$ & $.7302(5.61)$ \\
\hline Denmark & $.0553(0.45)$ & $.6225(4.99)$ & $.7215(5.80)$ & $.2404(1.85)$ & $.3729(2.87)$ \\
\hline East Germany & $.1292(1.03)$ & $.5526(4.36)$ & $-.5624(4.44)$ & $.7734(5.79)$ & $.6409(4.80)$ \\
\hline Eire & $-.2594(1.99)$ & $-.1577(1.21)$ & $-.1067(0.83)$ & $.0089(0.06)$ & $.6272(4.49)$ \\
\hline Finland & $-.2120(1.59)$ & $.4052(3.09)$ & $-.2080(1.59)$ & $.5606(4.05)$ & $.8269(5.98)$ \\
\hline France & $-.4340(3.71)$ & $-.2064(1.77)$ & $-.4127(3.50)$ & $.6858(5.39)$ & $.8769(6.87)$ \\
\hline Great Britain & $-.3541(2.91)$ & $.0783(0.64)$ & $-.2439(1.99)$ & $.8457(6.39)$ & $.9123(6.90)$ \\
\hline Greece & $-.7783(6.13)$ & $-.6978(5.59)$ & $-.3146(2.49)$ & $1.5151(10.88)$ & $1.1973(8.69)$ \\
\hline Italy & $-.7108(5.85)$ & $-.5028(4.13)$ & $-.0704(0.58)$ & $.8578(6.57)$ & $.4945(3.80)$ \\
\hline Luxembourg & $-.1047(0.73)$ & $.1740(1.21)$ & $-.0261(0.18)$ & $.5932(3.92)$ & $.4304(2.81)$ \\
\hline Netherlands & $.1884(1.53)$ & $.9078(7.33)$ & $.4300(3.45)$ & $.0193(0.15)$ & $-.0531(0.41)$ \\
\hline Northern Ireland & $-.3217(1.66)$ & $-.2827(1.44)$ & $-.4157(2.11)$ & $.4010(1.89)$ & $1.0523(4.95)$ \\
\hline Portugal & $-.5803(4.64)$ & $-.5188(4.18)$ & $-.2337(1.88)$ & $.7444(5.51)$ & $.9595(7.14)$ \\
\hline Spain & $-.5779(4.53)$ & $-.5185(4.09)$ & $-.2178(1.71)$ & $.2506(1.83)$ & $.1181(0.86)$ \\
\hline Sweden & $-.2496(2.08)$ & $.4780(3.98)$ & $-.0651(0.54)$ & $.6386(5.04)$ & $.1555(1.22)$ \\
\hline West Germany & $-.1288(1.04)$ & $.1367(1.09)$ & $.0526(0.42)$ & $.5801(4.41)$ & $.5673(4.29)$ \\
\hline Cut_1 & -3.7369 & -2.7130 & -2.5470 & -.0049 & -2.0073 \\
\hline Cut 2 & -2.5745 & -1.5398 & -1.7006 & 1.2993 & -.6503 \\
\hline
\end{tabular}




\begin{tabular}{|c|c|c|c|c|c|}
\hline Cut 3 & -1.6667 & -.6914 & -1.0584 & 3.3955 & 1.3568 \\
\hline Cut 4 & -.6690 & .2902 & -.2864 & 5.3846 & 3.2899 \\
\hline Cut_5 & .3270 & 1.2389 & .4884 & & \\
\hline Cut_6 & 1.4745 & 2.4235 & 1.5115 & & \\
\hline $\mathrm{N}$ & 7,121 & 7,118 & 7,118 & 7,109 & 7,089 \\
\hline Likelihood ratio & -12820.9 & -12305.1 & -12731.8 & -9401.3 & 9542.0 \\
\hline $\mathrm{LR} \mathrm{Chi}^{2}$ & 297.4 & 753.9 & 781.6 & 504.5 & 469.3 \\
\hline Pseudo $\mathrm{R}^{2}$ & .0115 & .0297 & .0298 & .0261 & .0240 \\
\hline
\end{tabular}




\begin{tabular}{|c|c|c|c|c|c|}
\hline & $(11)$ & (12) & (13) & (14) & $(15)$ \\
\hline & $\begin{array}{c}\text { Limits Family } \\
\text { Time }\end{array}$ & Tired & Fed up & Lose sleep & $\begin{array}{c}\text { Unhappy \& } \\
\text { depressed }\end{array}$ \\
\hline Self with employees & $.7626(7.98)$ & $.6637(7.12)$ & $.7260(7.45)$ & $.4194(4.30)$ & $.2106(2.12)$ \\
\hline Self no employees & $.4371(5.51)$ & $.1375(1.79)$ & $.2361(2.89)$ & $.1580(2.04)$ & $.0304(0.38)$ \\
\hline Years of schooling & $.0186(3.16)$ & $.0049(0.85)$ & $.0146(2.43)$ & $-.0086(1.42)$ & $-.0102(1.68)$ \\
\hline Private sector & $.1125(1.96)$ & $-.0219(0.39)$ & $.1140(1.90)$ & $-.0689(1.17)$ & $-.1048(1.75)$ \\
\hline Union member & $.2623(4.77)$ & $.3266(5.99)$ & $.2309(4.05)$ & $.1308(2.28)$ & $.1613(2.78)$ \\
\hline Years of tenure & $.0028(0.88)$ & $.0021(0.67)$ & $-.0002(0.08)$ & $-.0076(2.31)$ & $-.0047(1.41)$ \\
\hline Male & $.1647(3.46)$ & $-.1606(3.42)$ & $.2033(4.12)$ & $-.2655(5.41)$ & $-.3775(7.60)$ \\
\hline Age & $.0794(6.18)$ & $.0767(6.15)$ & $.0960(7.12)$ & $.0901(6.84)$ & $.0574(4.33)$ \\
\hline $\mathrm{Age}^{2}$ & $-.0011(6.98)$ & $-.0009(6.34)$ & $-.0011(6.88)$ & $-.0009(5.73)$ & $-.0005(3.46)$ \\
\hline Austria & $.6430(5.01)$ & $.5291(4.17)$ & $.6562(4.84)$ & $.0012(0.01)$ & $.3267(2.39)$ \\
\hline Denmark & $-.0082(0.06)$ & $.2973(2.33)$ & $.0882(0.65)$ & $-.8232(6.01)$ & $-.1979(1.42)$ \\
\hline East Germany & $.5561(4.14)$ & $.5697(4.34)$ & $.4951(3.57)$ & $.0120(0.09)$ & $.2627(1.88)$ \\
\hline Eire & $.1479(1.06)$ & $.3703(2.71)$ & $.0105(0.07)$ & $-.3222(2.32)$ & $-.1653(1.13)$ \\
\hline Finland & $.4111(2.96)$ & $.5533(4.09)$ & $.4286(2.99)$ & $-.0886(0.63)$ & $.6926(4.85)$ \\
\hline France & $.6500(5.05)$ & $.8563(6.81)$ & $.4908(3.65)$ & $.2509(1.99)$ & $.3855(2.91)$ \\
\hline Great Britain & $.5098(3.92)$ & $.5119(3.99)$ & $.4136(3.04)$ & $-.2544(1.91)$ & $.2363(1.73)$ \\
\hline Greece & $.9641(6.95)$ & $1.3041(9.59)$ & $.1800(1.27)$ & $.5307(3.88)$ & $.5913(4.21)$ \\
\hline Italy & $.3333(2.55)$ & $.4360(3.42)$ & $-.2109(1.53)$ & $.6001(4.57)$ & $.9073(6.69)$ \\
\hline Luxembourg & $.4433(2.88)$ & $.4091(2.75)$ & $.3757(2.37)$ & $-.1072(0.69)$ & $.0112(0.07)$ \\
\hline Netherlands & $-.0471(0.36)$ & $-.1514(1.19)$ & $-.0255(0.19)$ & $-.2193(1.65)$ & $-.0255(0.18)$ \\
\hline Northern Ireland & $.4568(2.28)$ & $.5210(2.60)$ & $.2320(1.11)$ & $-.0834(0.40)$ & $.1232(0.56)$ \\
\hline Portugal & $.9156(6.87)$ & $1.1036(8.39)$ & $.7337(5.29)$ & $.2700(2.02)$ & $.3352(2.39)$ \\
\hline Spain & $.6963(5.12)$ & $.6491(4.83)$ & $-.0961(0.67)$ & $.3955(2.92)$ & $.4004(2.82)$ \\
\hline Sweden & $.3853(3.02)$ & $.3747(3.01)$ & $.2698(2.04)$ & $-.7305(5.49)$ & $-.1678(1.23)$ \\
\hline West Germany & $.3123(2.36)$ & $.4880(3.78)$ & $.4357(3.15)$ & $-.4054(3.01)$ & $.2313(1.68)$ \\
\hline Cut_1 & .5842 & -.3094 & 1.7440 & 1.4262 & 1.0044 \\
\hline
\end{tabular}




\begin{tabular}{|l|l|l|l|l|l|}
\hline Cut_2 & 1.8674 & 1.0643 & 2.9258 & 3.1822 & 2.7551 \\
\hline Cut_3 & 3.3571 & 2.8060 & 4.4952 & 5.0093 & 4.5385 \\
\hline Cut_4 & 5.2144 & 4.8000 & 6.2135 & & \\
\hline & & & & & \\
\hline $\mathrm{N}$ & 6,742 & 7,055 & 6,397 & 7,125 & 7,122 \\
\hline Likelihood ratio & -9794.9 & -9926.2 & -8832.4 & -7683.6 & -7424.8 \\
\hline LR Chi ${ }^{2}$ & 456.0 & 434.0 & 378.9 & 432.5 & 341.2 \\
\hline Pseudo R & .0227 & .0214 & .0274 & .0225 \\
\hline Notes: excluded category Belgium. All equations include 11 industry dummies and 8 ‘ever been unemployed?' dummies. \\
Source: Eurobarometer 44.3OVR, February-April 1996 - ICPSR\#2443
\end{tabular}




\begin{tabular}{|c|c|c|c|c|c|}
\hline & $(16)$ & $(17)$ & $(18)$ & (19) & $(20)$ \\
\hline Self with employees & $-.2155(1.82)$ & $.1408(1.37)$ & $.4035(4.23)$ & $-.0581(0.44)$ & $.1429(5.41)$ \\
\hline Self no employees & $.1075(1.22)$ & $.1868(2.30)$ & $.1567(2.02)$ & $.0958(0.95)$ & $-.0081(0.38)$ \\
\hline Years of schooling & $-.0057(0.82)$ & $-.0087(1.36)$ & $.0216(3.62)$ & $-.0127(1.61)$ & $.0097(5.97)$ \\
\hline Private sector & $-.0269(0.40)$ & $-.1498(2.39)$ & $-.0344(0.58)$ & $-.0916(1.22)$ & $.0250(1.57)$ \\
\hline Union member & $.0460(0.70)$ & $.0615(1.01)$ & $.1177(2.08)$ & $.0863(1.19)$ & $.0736(4.81)$ \\
\hline Years of tenure & $-.0014(0.39)$ & $.0003(0.09)$ & $.0020(0.62)$ & $-.0069(1.65)$ & $.0034(3.92)$ \\
\hline Male & $-.3043(5.45)$ & $-.3720(7.19)$ & $-.1450(2.99)$ & $-.2411(3.86)$ & $.0305(2.32)$ \\
\hline Age & $.0362(2.42)$ & $.0444(3.22)$ & $.0852(6.56)$ & $.0225(1.34)$ & $.0211(6.02)$ \\
\hline $\mathrm{Age}^{2}$ & $-.0003(1.90)$ & $-.0004(2.71)$ & $-.0009(6.28)$ & $-.0001(0.76)$ & $-.0002(6.48)$ \\
\hline Austria & $.0164(0.11)$ & $.0107(0.08)$ & $-.2161(1.63)$ & $-.0453(0.30)$ & $.0756(2.04)$ \\
\hline Denmark & $-.8008(5.11)$ & $-.5715(3.92)$ & $-.3757(2.83)$ & $-.8479(5.12)$ & $.2111(5.83)$ \\
\hline East Germany & $-.6832(4.25)$ & $-.0462(0.32)$ & $.2652(1.98)$ & $-.5958(3.59)$ & $.1533(4.05)$ \\
\hline Eire & $-.3077(1.97)$ & $-.3569(2.37)$ & $-.4938(3.51)$ & $-.4937(2.95)$ & $.1188(3.07)$ \\
\hline Finland & $.0556(0.36)$ & $.1511(1.02)$ & $.3929(2.83)$ & $-.0427(0.27)$ & $.1178(3.02)$ \\
\hline France & $.1604(1.16)$ & $.4699(3.53)$ & $.3878(3.06)$ & $-.2956(1.98)$ & $.1286(3.63)$ \\
\hline Great Britain & $-.1660(1.14)$ & $-.2378(1.68)$ & $.1006(0.77)$ & $-.6684(4.16)$ & $.3174(9.05)$ \\
\hline Greece & $-.5794(3.63)$ & $.2120(1.49)$ & $.2133(1.57)$ & $-1.3952(7.09)$ & $.1221(3.23)$ \\
\hline Italy & $.1524(1.05)$ & $.7208(5.22)$ & $.7395(5.60)$ & $-.4786(3.00)$ & $.1523(4.16)$ \\
\hline Luxembourg & $-.2795(1.59)$ & $-.0875(0.52)$ & $-.0224(0.14)$ & $-.4222(2.25)$ & $.0384(0.90)$ \\
\hline Netherlands & $-.3975(2.64)$ & $-.4027(2.76)$ & $-.2479(1.86)$ & $-.8139(4.87)$ & $.1499(4.09)$ \\
\hline Northern Ireland & $-.1923(0.81)$ & $-.2382(1.03)$ & $-.0679(0.32)$ & $-.3139(1.25)$ & $.3090(5.66)$ \\
\hline Portugal & $-.3310(2.16)$ & $-.1192(0.82)$ & $.0044(0.03)$ & $-.5785(3.49)$ & $.1006(2.65)$ \\
\hline Spain & $-.0577(0.38)$ & $.3696(2.58)$ & $-.1290(0.94)$ & $-.6056(3.59)$ & $-.0607(1.55)$ \\
\hline Sweden & $-.8139(5.28)$ & $-.4591(3.26)$ & $-.2708(2.08)$ & $-.9814(5.94)$ & $.3906(11.43)$ \\
\hline West Germany & $-.3150(2.07)$ & $-.1257(0.87)$ & $.0757(0.57)$ & $-.5676(3.45)$ & $.1648(4.41)$ \\
\hline Cut_1 & 1.1198 & .8855 & 1.7206 & 1.1054 & \\
\hline Cut_2 & 2.8887 & 2.6998 & 3.4788 & 2.9297 & \\
\hline Cut_3 & 4.6145 & 4.7020 & 5.3704 & 4.5970 & \\
\hline
\end{tabular}




\begin{tabular}{|l|l|l|l|l|l|}
\hline & & & & \\
\hline $\mathrm{N}$ & 7,113 & 7,110 & 7,120 & 7,106 & 7,005 \\
\hline Likelihood ratio & -5657.9 & -6614.0 & -7909.3 & -4582.8 & -4472.8 \\
\hline LR Chi $^{2}$ & 262.9 & 378.3 & 315.1 & 217.9 & 643.4 \\
\hline Pseudo R & .0227 & .0278 & .0195 & .0232 & .0671 \\
\hline $\begin{array}{l}\text { Notes: excluded category Belgium. All equations include 11 industry dummies and 8 ‘ever been unemployed?’ dummies. * } \\
=\text { dprobit } \\
\text { Source: Eurobarometer 44.3OVR, February-April 1996 - ICPSR\#2443 }\end{array}$ \\
\hline
\end{tabular}


Table 9. Ordered Logits Regarding Satisfaction with Work and Leisure; Choice and Control and Life.

\begin{tabular}{|c|c|c|c|c|c|}
\hline & Work \& Leisure & \multicolumn{2}{|c|}{ Choice \& Control } & \multicolumn{2}{|c|}{ Life Satisfaction } \\
\hline & $(1)$ & $(2)$ & $(3)$ & $(4)$ & $(5)$ \\
\hline & WVS & WVS & WVS & EBS & EBS \\
\hline \multirow[t]{2}{*}{ Self-employment } & .0878 & .1500 & .1445 & .0749 & .0793 \\
\hline & $(2.60)$ & $(6.94)$ & $(6.91)$ & $(5.55)$ & $(6.06)$ \\
\hline \multirow[t]{2}{*}{ Retired } & & & -.1751 & & .0149 \\
\hline & & & $(7.73)$ & & $(1.41)$ \\
\hline \multirow[t]{2}{*}{ Housewife } & & & -.1431 & & .0519 \\
\hline & & & $(7.69)$ & & $(5.73)$ \\
\hline \multirow[t]{2}{*}{ Student } & & & -.1169 & & .0773 \\
\hline & & & $(4.91)$ & & $(3.84)$ \\
\hline \multirow[t]{2}{*}{ Unemployed } & & & -.3422 & & -1.0382 \\
\hline & & & $(15.63)$ & & $(81.18)$ \\
\hline \multirow[t]{2}{*}{ Other LM status } & & & -.2473 & & .1624 \\
\hline & & & $(5.69)$ & & $(1.14)$ \\
\hline \multirow[t]{2}{*}{ DK labor force status } & & & -.2713 & & \\
\hline & & & $(2.02)$ & & \\
\hline \multirow[t]{2}{*}{ Age } & .0214 & -.0223 & -.0185 & -.0290 & -.0240 \\
\hline & $(3.69)$ & $(6.81)$ & $(9.40)$ & $(15.58)$ & $(24.08)$ \\
\hline \multirow[t]{2}{*}{$\mathrm{Age}^{2}$} & .00004 & .0002 & .0002 & .0003 & .0003 \\
\hline & $(0.60)$ & $(5.07)$ & $(7.18)$ & $(15.10)$ & $(25.11)$ \\
\hline \multirow[t]{2}{*}{ Male } & .0212 & -.0912 & -.0907 & -.0775 & -.0559 \\
\hline & $(0.93)$ & $(6.62)$ & $(8.14)$ & $(9.10)$ & $(9.06)$ \\
\hline \multirow[t]{2}{*}{ Age left school } & -.0066 & .0148 & .0168 & $\mathrm{n} / \mathrm{a}$ & $\mathrm{n} / \mathrm{a}$ \\
\hline & $(3.35)$ & $(9.31)$ & $(13.65)$ & & \\
\hline Schooling dummies & No & No & No & 10 & 10 \\
\hline Workers only & Yes & Yes & No & Yes & No \\
\hline cut1 & -3.3753 & -3.6073 & -3.415 & -3.013 & -2.9466 \\
\hline cut2 & -2.2926 & -3.0826 & -2.899 & -1.3081 & -1.3073 \\
\hline cut3 & -.2717 & -2.4230 & -2.2817 & 1.6765 & 1.5178 \\
\hline cut4 & .7031 & -1.8717 & -1.7711 & & \\
\hline cut5 & & -.9081 & -.8418 & & \\
\hline cut6 & & -.3614 & -.3112 & & \\
\hline cut7 & & .3207 & .3369 & & \\
\hline cut8 & & 1.2880 & 1.2549 & & \\
\hline cut9 & & 2.0081 & 1.9367 & & \\
\hline $\mathrm{N}$ & 28,284 & 71,158 & 119,909 & 236,993 & 483,990 \\
\hline $\mathrm{Chi}^{2}$ & 6884.3 & 6558.4 & 11507.6 & 4144.1 & 80983.6 \\
\hline
\end{tabular}




\begin{tabular}{l}
\hline Pseudo R ${ }^{2}$ \\
Source: World Values Surveys (WVS) 1981-1997 (ICPSR \#2790); Eurobarometer Trend file (EBS) \\
1975-1998 excluding 1995 \& 1996 (ICPSSR\# 3384) \\
Ordered logit in column 1 is for 1995 and includes 45 countries (Andalusia, Argentina, Armenia, \\
Australia, Azerbaijan, Bangladesh, Basque, Belarus, Bosnia-Herzegovina, Brazil, Bulgaria, Chile, \\
China, Croatia, Dominican Republic, East Germany, Estonia, Finland, Galicia, Georgia, India, Japan, \\
Latvia, Lithuania, Macedonia, Mexico, Moldova, Montenegro, Nigeria, Norway, Peru, Philippines, \\
Russia, Serbia, Slovenia, Spain, Sweden, Switzerland, Tambov, Turkey, Ukraine, Uruguay, USA, \\
Valencia, Venezuela, West Germany) \\
Equations in columns 2 \& 3 include two year dummies and 64 country dummies (Andalusia, \\
Argentina, Armenia, Australia, Austria, Azerbaijan, Bangladesh, Basque, Belarus, Belgium, Bosnia- \\
Herzegovina, Brazil, Bulgaria, Canada, Chile, China, Croatia, Czech Republic, Denmark, Dominican \\
Republic, East Germany, Estonia, Finland, France, Galicia, Georgia, Great Britain, Hungary, Iceland, \\
India, Ireland, Italy, Japan, Latvia, Lithuania, Macedonia, Mexico, Moldova, Montenegro, Moscow, \\
Netherlands, Nigeria, Northern Ireland, Norway, Peru, Philippines, Poland, Portugal, Romania, \\
Russia, Serbia, Slovakia, Slovenia, South Africa, Spain, Sweden, Switzerland, Tambov, Turkey, \\
Ukraine, Uruguay, USA, Valencia, Venezuela, West Germany). World Values Study equations also \\
include an insignificant part-time dummy - results not reported. Excluded category >=30 hrs per \\
week. \\
In columns 5 and 6 there are 21 year dummies and 17 country dummies (countries are Austria, \\
Belgium, Denmark, East Germany, Finland, France, Great Britain, Greece, Ireland, Italy, \\
Luxembourg, Netherlands, Northern Ireland, Norway, Portugal, Spain, Sweden and West Germany). \\
Excluded category = employees.
\end{tabular}


Appendix 1 -questions from Eurobarometer 44.3OVR, February-April 1996 - ICPSR\#244

Q.36.a) I am going to read out a list of various aspects of jobs. Please choose between the two ends of this scale. If you are completely dissatisfied with that particular aspect of your present job, you give a score of 1 . If you are completely satisfied with that particular aspect of your present job, you give a score of 7 . The scores between 1 and 7 allow you to say how close to either side you are.

1. Your pay?

2. The opportunity to use your abilities?

3 . Being able to use your own initiative?

4. The hours you work?

5. The amount of work?

6 . The variety in the work?

7. Your job security?

8. The relations with your supervisor or manager?

9. Your promotion prospects?

10. The training provided?

Q.36.b) All in all, how satisfied would you say you are with your job?

Q.37. How often do you...?

1. Find your work stressful?

2. Come home from work exhausted?

3. Find your job prevents you from giving the time you want to your partner or family?

4. Feel too tired after work to enjoy the things you would like to do at home?

5. Find that your partner/family gets fed up with the pressure of your job?

Responses here are 'Always; Often; Sometimes; Hardly ever, Never.

Q.83. Would you say that you have not at all, no more than usual, rather more than usual, much more than usual?

1. Lost much sleep over worry?

2. Been feeling unhappy and depressed?

3 . Been losing confidence in yourself?

4. Been feeling you could not overcome your difficulties?

5 . Been feeling constantly under strain?

6 . Been thinking of yourself as a worthless person?

Q.19. For each of the following statements, please tell me if it applies to you, or not?

I work under a great deal of pressure - yes, no or don't know? 
Appendix 2. . Questions in the World Values and Eurobarometer Surveys.

A). Questions in the World Values Survey.

V72. Work and Leisure. Which point on this scale most clearly describes how much weight you place of work (including housework and school work), as compared with leisure or recreation?

1. It's leisure that makes life worth living, not work

2.

3.

4.

5. Work is what makes life worth living, not leisure

9. DK

V66. Choice and Control. Some people feel they have completely free choice and control over their lives, while other people feel that what they do has no real effect on what happens to them. Please use this scale where 1 means "none at all" and 10 means "a great deal" to indicate how much freedom of choice and control you feel you have over the way your life turns out. *

B) Questions in the Eurobarometer

Variable $=$ Satislfe. On the whole are you very satisfied, fairly satisfied, not very satisfied or not at all satisfied with the life you lead. Would you say you are

1. very satisfied

2. fairly satisfied

3. not very satisfied

4. not at all satisfied 
Figure 1: Self-employment Rates, 1956-2002.
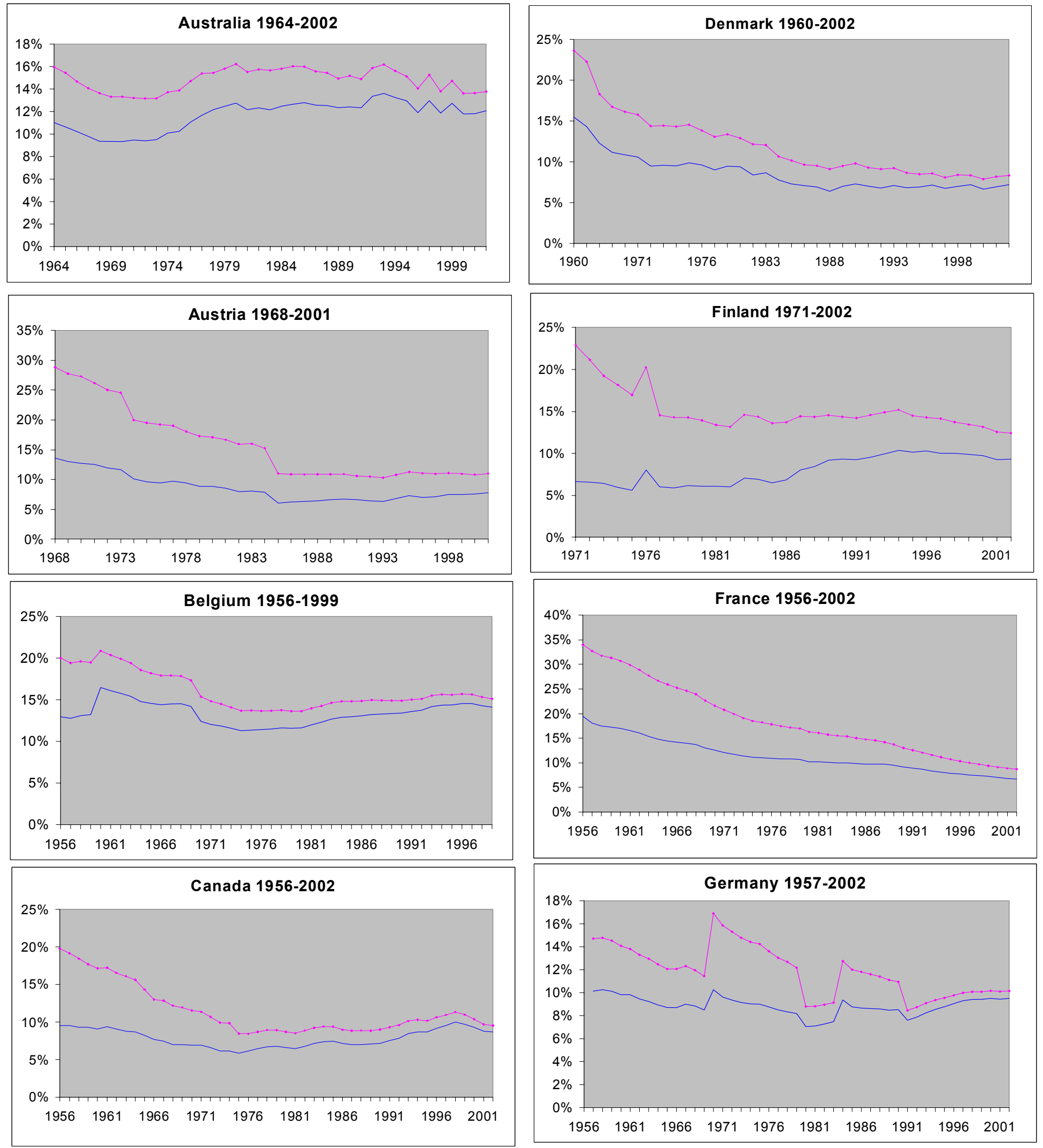

SOURCE: http://www1.oecd.org/scripts/cde/members/LFSDATAAuthenticate.asp

Total Sectors $\diamond$ Non-Agricultural 
Figure 1 (cont.):
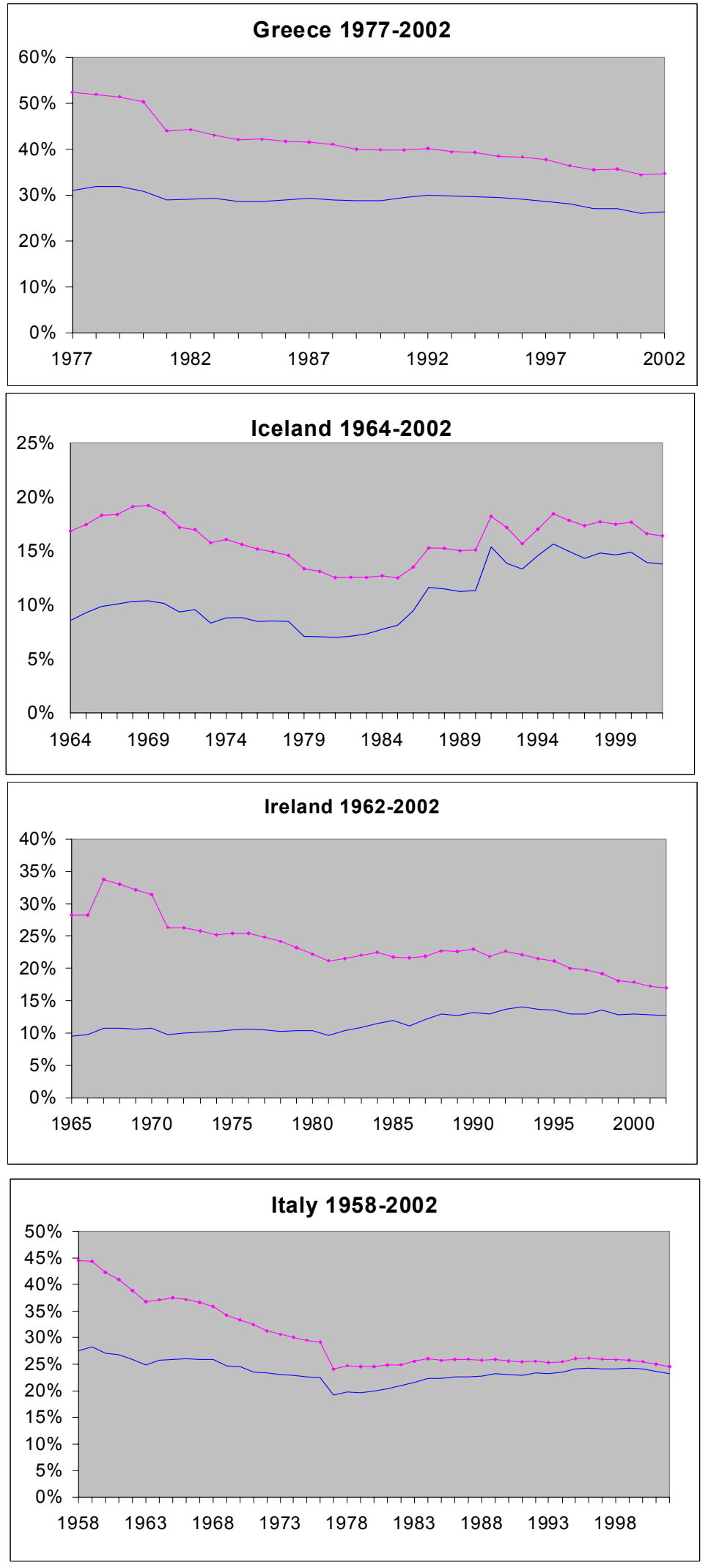
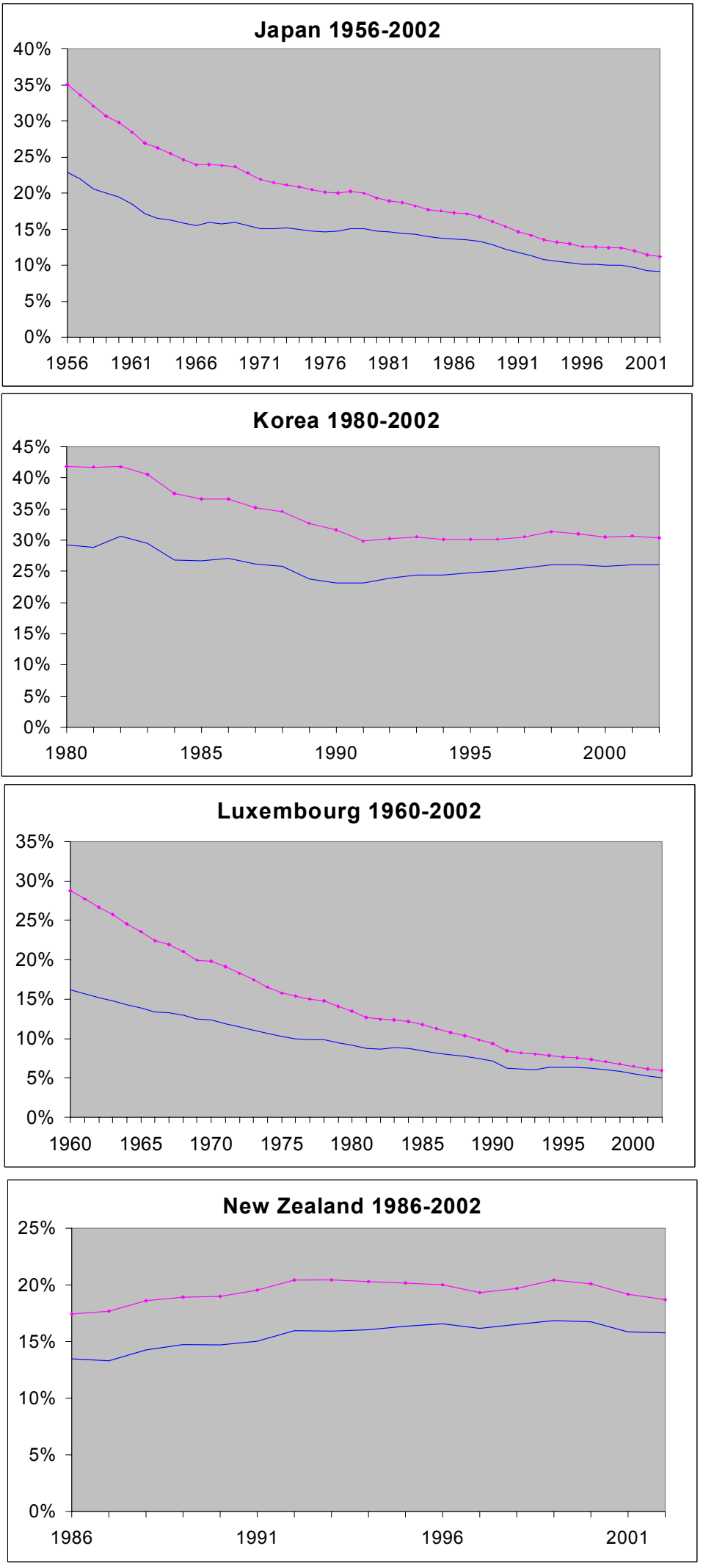

SOURCE: http://www1.oecd.org/scripts/cde/members/LFSDATAAuthenticate.asp

Total Sectors $\diamond$ Non-Agricultural 
Figure 1 (cont.):
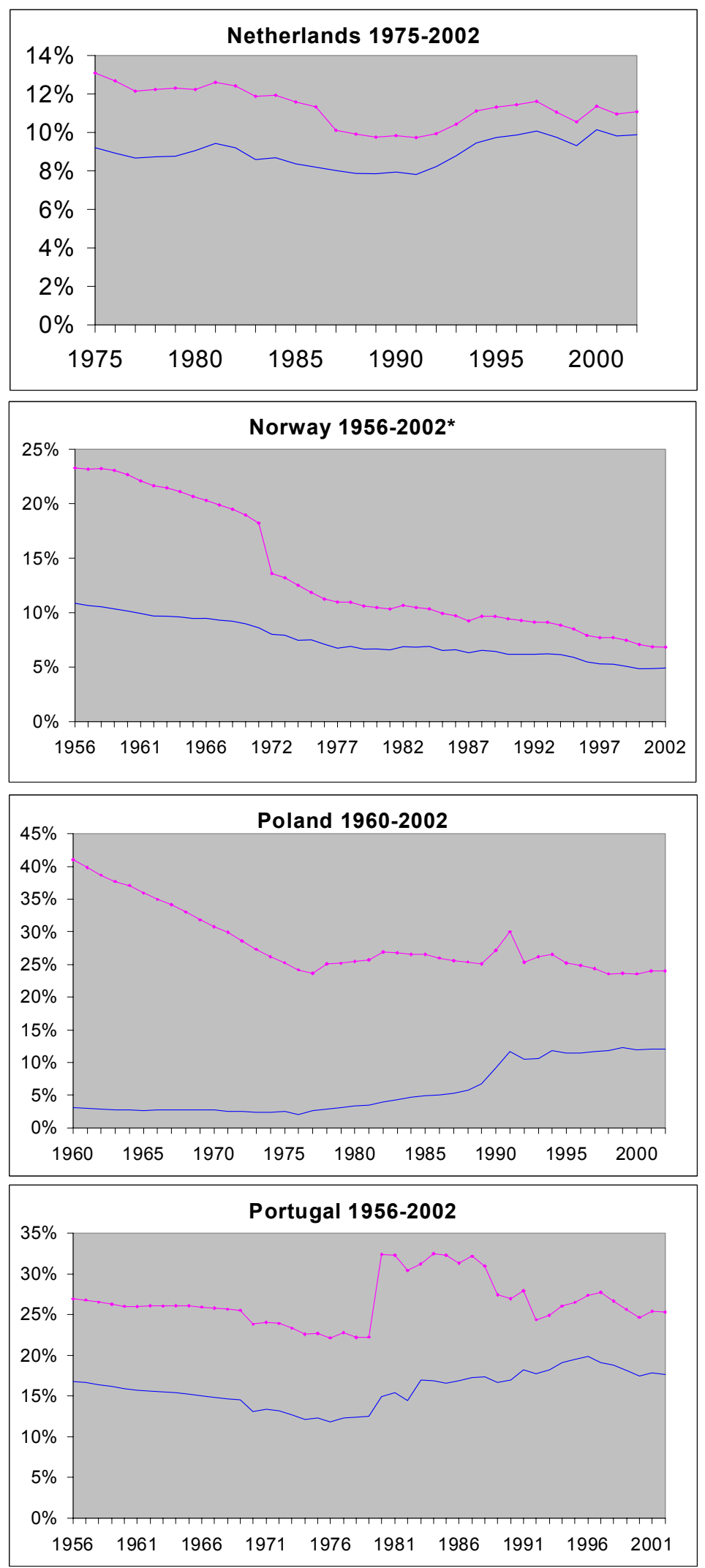
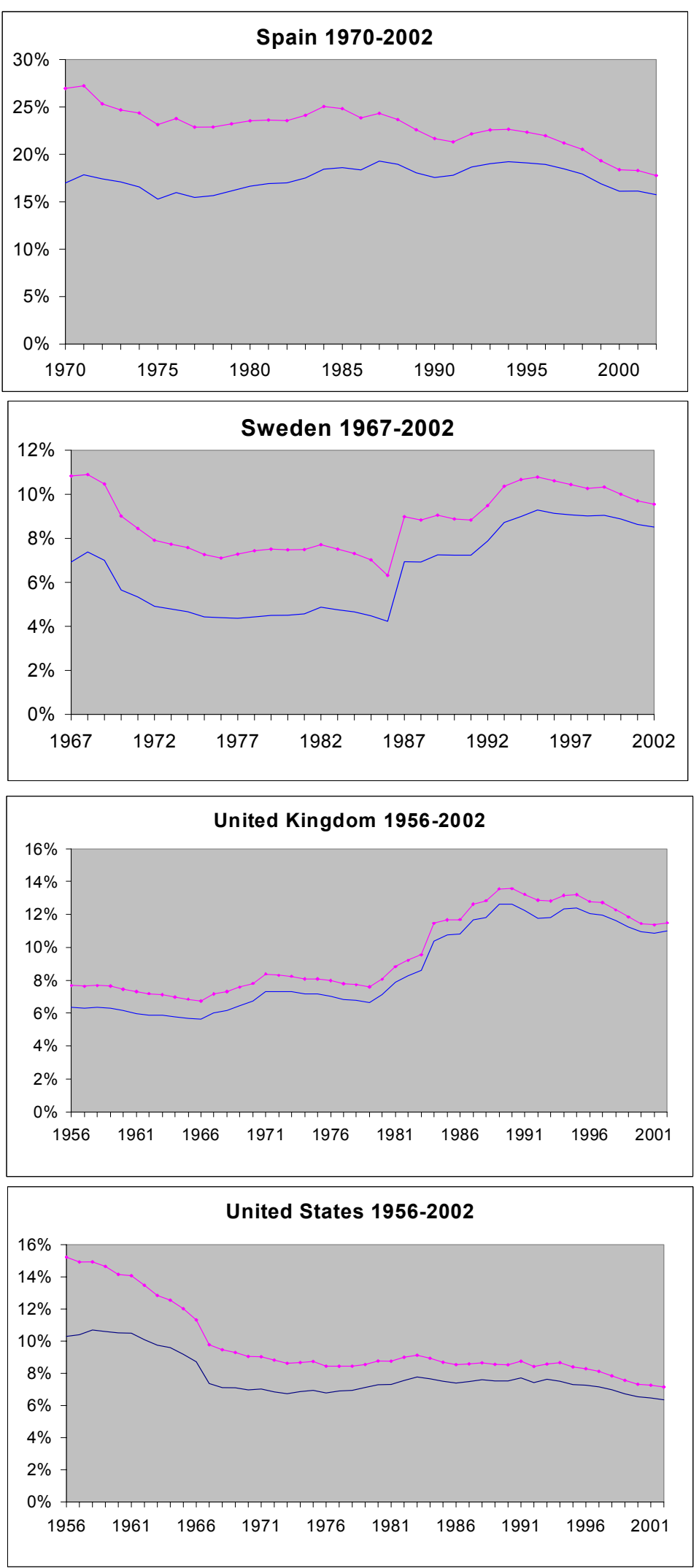

SOURCE: http://www1.oecd.org/scripts/cde/members/LFSDATAAuthenticate.asp

Total Sectors $\diamond$ Non-Agricultural 


\section{$\underline{\text { References }}$}

Acs, Z. and D. Evans (1994), 'The determinants of variations in self-employment rates across countries and over time', working paper.

Alba-Ramirez, A. (1994), 'Self-employment in the midst of unemployment; the case of Spain and the United States', Applied Economics, 26, pp. 189-204.

Andersson, P. and E. Wadensjö, (2003), 'Self-employed immigrants in Denmark and Sweden a way to economic self-reliance?', Swedish Institute for Social Research, Stockholm University.

Arai, A.B. (1997). 'The road not taken: The transition from unemployment to self-employment in Canada, 1961-1994', Canadian Journal of Sociology, 22(3), Summer, pp. 365-382.

Aronson, R.L. (1991), Self-employment, ILR Press, Ithaca, New York.

Ashenfelter, O. (1972), 'Racial discrimination and trade unionism', Journal of Political Economy, 80(3), Part 1, May-June, pp. 435-464.

Bates, T., (1989), 'The changing nature of minority business: a comparative analysis of Asian, non-minority, and black-owned businesses,' The Review of Black Political Economy, pp. 25-42.

Bates, T., (1999), 'Exiting self-employment: an analysis of Asian immigrant-owned small businesses", Small Business Economics, 13, pp. 171-183.

Benz, M. and B.S. Frey (2003), 'The value of autonomy; evidence from the self-employed in 23 countries', Institute for Empirical Research in Economics, University of Zurich WP\#173.

Bernhardt, I. (1994), 'Comparative advantage in self-employment and paid work', Canadian Journal of Economics, May, pp. 273-289.

Birch, D.L. (1979), The job generation process, MIT Program on neighbourhood and regional change, Cambridge, MA.

Black, J., De Meza, D. and D. Jeffreys (1996), 'House prices, the supply of collateral, and the enterprise economy', Economic Journal, 106, January, pp. 60-75.

Black, D., D. Holtz-Eakin and S. Rosenthal (2001), 'Racial minorities, economic scale, and the geography of self-employment', Brookings-Wharton Papers on Urban Affairs, pp. 245-286.

Blanchflower, D.G., (2000), 'Self-employment in OECD countries', Labour Economics, 7, September, pp. 471-505.

Blanchflower, D.G., (2001), 'Unemployment, well-being, and wage curves in Eastern and Central Europe', Journal of the Japanese and International Economies, 15(4), December, pp. 364-402. 
Blanchflower, D.G. and R.B. Freeman (1994), 'Did the Thatcher reforms change British labour market performance?', in R. Barrell (Ed.), The UK labour market. Comparative aspects and institutional developments, Cambridge University Press.

Blanchflower, P. Levine and D. Zimmerman (2003), 'Discrimination in the small business credit market, Review of Economics and Statistics, November, 85(4), pp. 930-943.

Blanchflower, D. G. and B. Meyer (1994), 'A longitudinal analysis of the young self-employed in Australia and the United States', Small Business Economics, 6, pp. 1-20.

Blanchflower, D. G. and A.J. Oswald (1990), 'Self-employment and the enterprise culture', in British Social Attitudes: the 1990 Report, edited by Jowell, R. and Witherspoon, S., Gower Press, Aldershot.

Blanchflower, D. G. and A.J. Oswald (1998), 'What makes an entrepreneur?', Journal of Labor Economics, January, 16(1) pp. 26-60.

Blanchflower, D. G. and A.J. Oswald (1999), 'Job security and the decline in American job satisfaction', mimeo, Dartmouth College.

Blanchflower, D. G. and A.J. Oswald (2000), "Is the UK moving up the international wellbeing rankings?", April.

Blanchflower, D. G. and A.J. Oswald (2004), 'Well-being over time in Britain and the United States', forthcoming in the Journal of Public Economics.

Blanchflower, D. G., A.J. Oswald and A. Stutzer, (2001), 'Latent entrepreneurship across nations," European Economic Review, 45(4-6), May, pp. 680-691.

Blanchflower, D.G. and J. Wainwright (2004), 'Minority and female self-employment in the USA', mimeo, Dartmouth College.

Blau, D.M. (1986), 'Self-employment, earnings, and mobility in Peninsular Malaysia', World Development, 14(7), July, pp. 839-52

Blau, D. (1987), 'A time-series analysis of self-employment in the United States', Journal of Political Economy, 95, pp. 445-467.

Bogenhold, D. and U. Staber (1991), 'The decline and rise of self-employment', Employment and Society, 5, pp. 223-239.

Borjas, G. (1986), 'The self-employment experience of immigrants', Journal of Human Resources, 21(4), Winter, pp.485-506.

Borjas, G. J. and S. Bronars (1989), 'Consumer discrimination and self-employment', Journal of Political Economy, 97, pp. 581-605. 
Borooah, V.K and M. Hart (1999), 'Factors Affecting Self-Employment among Indian and Black Caribbean Men in Britain', Small Business Economics, 13, pp. 111-129.

Clark, K, and S. Drinkwater (2000), "Pushed out or pulled in? Self-employment among ethnic minorities in England and Wales", Labour Economics, 7, pp. 603-628.

Brossard, N., R. Chami and G. Hess, (2003), '(Why) do self-employed parents have more children', Working Paper, September.

Bruce, D. and H.J. Schuetze (2003), 'The labor market consequences of experience in selfemployment', working paper.

Burke, A.E., F.R. Fitzroy and M.A. Nolan (2000), "When less is more: distinguishing between entrepreneurial choice and performance", Oxford Bulletin of Economics and Statistics, 62(5), pp. $565-587$.

Burke, A.E., F.R. Fitzroy and M.A. Nolan (2002), 'Self-employment wealth and job creation: the roles of gender, non-pecuniary motivation and entrepreneurial ability', Small Business Economics, 19, pp. 255-270.

Carrasco, R. (1999), 'Transitions to and from self-employment in Spain: an empirical analysis' Oxford Bulletin of Economics and Statistics, 61(3), August, pp. 315-41

Coate, S. and S. Tennyson (1992), 'Labor market discrimination, imperfect information and selfemployment', Oxford Economic Papers, 44, pp. 272-288.

Cowling M, and P. Mitchell (1997), 'The evolution of UK self-employment: a study of government policy and the role of the macroeconomy', Manchester School of Economic and Social Studies, 65(4), September, pp. 427-442.

Davis, S.J., J.C. Haltiwanger and S. Schuh (1996), Job creation and destruction, MIT Press, Cambridge, MA.

De Witt, G. and F.A. Van Winden (1990), 'An empirical analysis of self-employment in the Netherlands', Economics Letters, 32, pp. 97-100.

Di Tella, R., R. J. MacCulloch and A,J. Oswald (2001), 'Preferences over Inflation and Unemployment: Evidence from Surveys of Happiness', American Economic Review, March, 91, pp. 335-341

Di Tella, R., R. J. MacCulloch and A,J. Oswald (2003), 'The macroeconomics of happiness' Review of Economics and Statistics, 85(4), November, pp. 809-827

Eden, D. (1992). 'Self-employed workers; a comparison group for organizational psychology', Organizational Behavior and Human Performance, 9(2), pp. 186-215. 
Evans, D. and B. Jovanovic (1989), 'An estimated model of entrepreneurial choice under liquidity constraints', Journal of Political Economy, 97, pp. 808-827.

Evans, D. and L. Leighton (1989), 'Some empirical aspects of entrepreneurship', American Economic Review, 79, pp. 519-535.

Fairlie, R. W. (1999) 'The absence of the African-American owned business: an analysis of the dynamics of self-employment', Journal of Labor Economics, 17(1), pp. 80-108.

Fairlie, R. W., and B.D. Meyer (1996): 'Ethnic and racial self-employment differences and possible explanations,' Journal of Human Resources, 31(4), pp. 757-793.

Fairlie, R.W and B.D. Meyer, (1998), 'Does immigration hurt African-American selfemployment?', in Help or Hindrance? The Economic Implications of Immigration for AfricanAmericans, eds., Daniel S. Hamermesh and Frank D. Bean, New York: Russell Sage Foundation.

Fairlie, R.W. and B.D. Meyer (2004), 'The effect of immigration on native self-employment, forthcoming in Journal of Labor Economics.

Fairlie, R.W. and B.D. Meyer, (2000), 'Trends in self-employment among white and black men during the twentieth century', Journal of Human Resources, XXXV(4), pp. 643-669.

Fölster, S. (2000), 'Do entrepreneurs create jobs?', Small Business Economics, 14, pp. 137-148.

Foti A. and M. Vivarelli (1994), 'An econometric test of the self-employment model - the case of Italy’, Small Business Economics, 6(2), April, pp. 81-93.

Frey, B.S. and M. Benz (2002), 'Being independent is a great thing: subjective evaluations of self-employment and hierarchy', Institute for Empirical Research in Economics, University of Zurich WP\#135.

Frey, B.S. and A. Stutzer (2003), 'Economic consequences of mispredicting utility', Institute for Empirical Research in Economics, University of Zurich, November.

Fuchs, V. (1982), 'Self-employment and labor force participation of older males', Journal of Human Resources, 17, Fall, pp. 339-357.

Genda, Y and R. Kambayashi (2002), 'Declining self-employment in Japan', Journal of the Japanese and International Economies, vol. 16 (1), March, pp. 73-91

Georgellis,Y., and H. J. Wall, (1999), 'Gender differences in self-employment: Panel Evidence from the Former West Germany', Working Paper 99-008B, Federal Reserve Bank of St. Louis (January), Mimeo. 
Hammarstedt, M. (2001), 'Immigrant self-employment in Sweden -- its variation and some possible determinants', Entrepreneurship and Regional Development, 13(2), April-June, pp. 147161.

Harhoff, D., K. Stahl, and M. Waywood (1998), 'Legal form, growth and exit of West German firms - empirical results for manufacturing construction, trade, and service industries', Journal of Industrial Economics, 46 (December), pp. 453-88.

Holmes, T. J. and J.A. Schmitz (1990), 'A theory of entrepreneurship and its application to the study of business transfers', Journal of Political Economy, 89, pp. 265-294.

Holtz-Eakin, D., Joulfaian, D., and H.S. Rosen (1994a), 'Entrepreneurial decisions and liquidity constraints', Journal of Political Economy, 102, pp. 53-75.

Holtz-Eakin, D., Joulfaian, D., and H.S. Rosen (1994b), 'Sticking it out: entrepreneurial survival and liquidity constraints', Rand Journal of Economics, Summer, 25(2), pp. 334-347.

Hout, M. and H.S. Rosen (2000), 'Self-employment, family background and race', Journal of Human Resources, 15(4), pp. 670-692.

Hundley, G. (2001), 'Why and when are the self-employed more satisfied with their work?', Industrial Relations, 40(2), April, pp. 293-316.

Johansson, E. (2000a), 'Self-Employment and liquidity constraints: evidence from Finland, Scandinavian Journal of Economics, 102(1), March, pp. 123-34.

Johansson, E. (2000b), 'Self-employment and the predicted earnings differential--Evidence from Finland', Finnish Economic Papers, 13(1), Spring, pp. 45-55.

Johnson, W.A. (1985), 'Women and self-employment in urban Tanzania', $\underline{\text { Review of Black }}$ Political Economy, 14(2-3), Fall-Winter 1985-86, pp. 245-57.

Kanbur, S.M.R. (1982), 'Entrepreneurial risk taking, inequality, and public policy: an application of inequality decomposition analysis to the general equilibrium effects of progressive taxation', Journal of Political Economy, 90, pp. 1-21.

Katz, J.A. (1993). 'How satisfied are the self-employed: a secondary analysis approach', Entrepreneurship Theory and Practice, 17(3), pp, 35-51.

Kelly, R., C. Mulvey and P.E.T. Lewis (2002), 'Self-employment programs and outcomes for disadvantaged jobseekers', Australian Bulletin of Labour, 28(4), December, pp. 247-71

Kidd, M., (1993) 'Immigrant wage differentials and the role of self-employment in Australia', Australian Economic Papers; 32(60), June, pp. 92-115. 
Kangasharju, A. and S. Pekkala (2002), 'The role of education in self-employment success in Finland', Growth and Change, 33(2), Spring, pp. 216-37

Kihlstrom, R.E. and J.J. Laffont (1979), 'A general equilibrium entrepreneurial theory of firm formation based on risk aversion', Journal of Political Economy, 87, pp. 719-848.

Kontos, M. (2003), 'Self-employment policies and migrants' entrepreneurship in Germany', Entrepreneurship and Regional Development, 15(2), April-June, pp. 119-35

Kosanovich, W.T. and H. Fleck (2001), 'Comprehensive statement of self-employment assistance programs', with B.Yost, W. Armon and S. Siliezar, U.S. Department of Labor, Office of Workforce Security ref \# 811-15, June. Downloadable from http://www.ows.doleta.gov/dmstree/op/op2k1/op_03-01.pdf

Kuhn, P.J. and H.J. Schuetze (2001), 'Self-employment dynamics and self-employment trends: a study of Canadian men and women, 1982-1998', Canadian Journal of Economics, vol. 34, no. 3, August, pp. 760-784.

Laferrere, A. and P. McEntee (1995), 'Self-employment and intergenerational transfers of physical and human capital: an empirical analysis of French data', Economic and Social Review; 27(1), October, pp. 43-54.

Le, A.T. (1999), “Empirical Studies of self-employment', Journal of Economic Surveys, 13(4), pp. 381-416.

Lentz B.F. and D.N. Laband (1990), 'Entrepreneurial success and occupational inheritance among proprietors', Canadian Journal of Economics, 23, pp. 563-579.

Lindh T., and H. Ohlsson (1996). 'Self-employment and windfall gains: evidence from the Swedish lottery', Economic Journal, 106: (439), November, pp.1515-1526.

Lindh, T. and H. Ohlsson (1998), 'Self-employment and wealth inequality', Review of Income and Wealth, 44(1), March, pp. 25-42

Lofstrom, M. (2002), 'Labor market assimilation and the self-employment decision of immigrant entrepreneurs', Journal of Population Economics, 15(1), January, pp. 83-114

Long, J.E., (1982), 'The income tax and self-employment', National Tax Journal, 35, March, pp. $31-42$.

Manski, C.F. and J.D. Straub (2000), 'Worker Perceptions of Job Insecurity in the Mid-1990s: Evidence from the Survey of Economic Expectations', Journal of Human Resources, 35(3), Summer, pp. 447-79.

Meager, N. (1992), 'Does unemployment lead to self-employment?', Small Business Economics, 4, pp. 87-103. 
Nziramasanga, M. and M. Lee, (2001), 'Duration of self-employment in developing countries: evidence from small enterprises in Zimbabwe', Small Business Economics, 17(4), December, pp. 239-53

Ozcan, Y.Z.; Ucdogruk, S. and K. Metin Ozcan (2003), 'Wage differences by gender, wage and self employment in urban Turkey', Journal of Economic Cooperation among Islamic Countries, 24(1), January, pp. 1-24.

Parker, S.C. (2002), "Do Banks ration credit to new enterprises and should governments intervene?", Scottish Journal of Political Economy, 49(2), May, pp. 162-195.

Pfeiffer, E., and W. Pohlmeier (1992), 'Uncertainty, and the probability of self-employment", Recherche Economiques de Louvain, 58, (3-4), pp. 265-81.

Pickles, A.R. and P.N. O'Farrell (1987), 'An analysis of entrepreneurial behavior from male work histories', Regional Studies, 21, pp. 425-444.

Quinn, J.F. (1980), 'Labor force participation patterns of older self-employed workers', $\underline{\text { Social }}$ Security Bulletin, 43, pp. 17-28.

Reardon, E. (1998), 'Are the self-employed misfits or superstars?', Rand Corporation, working paper.

Rees, H. and A. Shah (1986), 'An empirical analysis of self-employment in the UK', Journal of Applied Econometrics, 1, pp. 95-108.

Robson, M.T. (1998a), 'The rise in self-employment amongst UK males', Small Business Economics, 10: (3), pp.199-212.

Robson, M.T. (1998b), 'Self-employment in the UK regions', Applied Economics, 30: (3) pp. 313-322.

Schuetze, H.J. (2000), 'Taxes, economic conditions and recent trends in male self-employment; a Canada-U.S. comparison', Labour Economics, vol. 7, no. 5, September, pp. 507-44

Schmidt, S.R. (1999), 'Long-run trends in worker's belief about their own job security: Evidence from the General Social Surveys', Journal of Labor Economics, October, Part 2, 017(4), pS127S141.

Spector P.E., Cooper C.L., Sanchez J.I., O'Driscoll M., Sparks K., Bernin P., Bussing A., Dewe P., Hart P., Lu L., Miller K., De Moraes L.F.R., Ostrognay G.M., Pagon M., Pitariu O., Poelmans S., Radhakrishnan P., Russinova V., Salamatov V., Salgado J., Shima S., Siu O.L., Stora J.B., Teichmann M., Theorell T., Vlerick P., Westman M., Widerszal-Bazyl M., Wong P., Yu S.F. (2001), 'Do national levels of individualism and internal locus of control relate to well- 
being: an ecological level international study', Journal of Organizational Behavior, 22 (8), December, pp. 815-832.

Taylor, M.P. (1996), 'Earnings, independence or unemployment; why become self-employed?', Oxford Bulletin of Economics and Statistics, 58(2), pp. 253-265.

Vijverberg, W.P.M. (1991), 'Profits from self-employment: The case of Cote d'Ivoire', World Development, 19(6), June, pp. 683-696

Vijverberg, W.P.M (1995), 'Returns to schooling in non-farm self-employment: an econometric case study of Ghana', World Development, 23(7), July, pp. 1215-27

Wagner, J. (2003), 'The impact of personal characteristics and the regional milieu of the transition from unemployment to self-employment: empirical evidence for Germany', Jahrbucher fur Nationalokonomie und Statistik, vol. 223(2), March, pp. 204-22

Weaver, C.N. and R.S. Franz (1992), 'Work-related attitudes of entrepreneurs, public and private employees', Psychological Reports, 70(2), pp.387-390.

Williams, C. (2003), "Sources of Workplace Stress', Perspectives on Labour and Income, 15(3), Autumn, pp. 23-30

Williams, D.R. (2003), 'Returns to education and experience in self-employment: evidence from Germany', Schmollers Jahrbuch: Zeitschrift fur Wirtschafts- und Sozialwissenschaften/Journal of Applied Social Science Studies, 123(1), pp. 139-150.

Yuengert, A.M. (1995), 'Testing hypotheses of immigrant self-employment', Journal of Human Resources, 30(1), Winter, pp.194-204.

Zhengxi; L. J. Compton and G. Picot (1999), 'Rising self-employment in the midst of high unemployment: an empirical analysis of recent developments in Canada', Canadian Business Economics, 7(4), December, pp. 65-78

Zhengxi; L. G. Picot and J. Compton (2000), 'The entry and exit dynamics of self-employment in Canada', Small Business Economics, 15(2), September, pp. 105-25. 